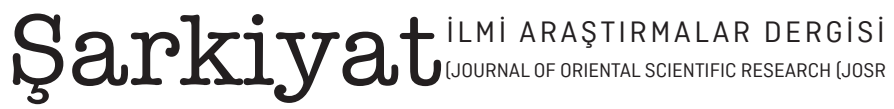 \\ Cilt/Volume: 13, Sayı/Issue: 3 (Aralık/December 2021]
}

\section{WERGEREKE Ji EREBî BO FELLîHî Û KURDÎ-GERŞÛNÎ Di KOLEKSÎYONA EDUARD SACHAU DE (ÇîROKA SED Û ŞÊST Û DUYEM A HEZAR ŞEV Û ŞEVEKÊ]}

Kenan SUBAŞI

Mardin Artuklu Üniversitesi, Türkiye'de Yaşayan Diller Enstitüsü, Kürt Dili ve Kültürü Anabilim Dalı, kenanenado@gmail.com https://orcid.org/0000-0001-7744-1646

\section{Lokman DiREKÇi}

Mardin Artuklu Üniversitesi, Türkiye'de Yaşayan Diller Enstitüsü, Süryani Dili ve Kültürü Anabilim Dalı, lokmandirekci@artuklu.edu.tr https://orcid.org/0000-0002-9548-4997

\section{Article Types / Makale Türü}

Research Article / Araştırma Makalesi

\section{Received / Makale Geliş Tarihi \\ 01/09/2021}

\section{Accepted / Kabul Tarihi}

$17 / 12 / 2021$ 
WERGEREKE JI EREBî BO FELLÎHî Û KURDÎ-GERŞÛNÎ DI KOLEKSÎYONA EDUARD SACHAU DE (ÇÎROKA SED Û ŞÊST Û DUYEM A HEZAR ŞEV Û ŞEVEKÊ]

\section{KURTE}

Fellîhî devokeke zimanê Siryanîya rojhilat (Sûrat) e ku li gorî Jeremias Schamir (Yeremya Şamîr 1821-1906) ew ji aliyê şênîyên devdora Eynkawaya Hewlêrê û mintiqeya Mûsilê ve tê axaftin. Jeremias Schamir keşişşek e ku di sedsala 19an de li devera Musilê jiyaye û mustensîxê gelek destxetên Gerşûnî (navê metnên zimanê bîyanî yên bi alfabeya Siryanî hatine nivîsîn) ye. Schamir ji bo rojhilatnasê Almanî Eduard Sachau (18451930) xebitîye û gelek destxetên Fellîhî, Erebî û Kurdî (Gerşûnî) îstinsax kirine û ji Sachau re şandine. Yek ji van destxetan bi navê Sachau 200 li Pirtûkxaneya Eyaletî ya Berlînê-Mîrateya Çandî ya Prûsyayê (Staatsbibliothek zu Berlin-Preußischer Kulturbesitz) di nav koleksîyona Destxetên Rojhilat (Orientalische Handschriften) de hatiye qeydkirin. Di vê destxetê de digel ferhengokeke rêzimanî ya Erebî-Fellîhî-Kurdî çend hîkayet, çîrok, destan û kilam jî cih digirin. Di vê xebata me de em ê ji wan hîkayetan, a bi navê Şebê Şêst $\hat{u}$ Dû-Ji Çîroka Hezar Şeb û Şebek bixebitin ku weku wergera ji Erebî bo Fellîhî û Kurdî hatiye kirin. Ev destxet bi tevahî ji 66 wereqan pêk tê ku çîroka navborî ji wereqa $29 \mathrm{v}$ dest pê dike heya wereqa 33r dewam dike. Digel nasandina vê destxetê, di vê lêkolînê de çîroka me ya navborî hatiye latînîzekirin jî. Ji bilî wê, berawirdkirina vê çîrokê bi ya Erebî û wergerên din ên îroyîn re jî hatiye kirin. Di encama vê xebatê de wergereke ji zimanên bîyanî bo Kurdî ya ku di sala 1883yan de hatiye kirin, peyda bû û bi lêkolîneran re hat parvekirin.

Bêjeyên Sereke: Erebî, Fellîhî, Kurdî, Gerşûnî, Werger, Çîrok, Hezar û Yek Şev, Jeremias Schamir, Eduard Sachau, Destxet.

\section{A TRANSLATION FROM ARABIC TO FELLIHI AND KURDISH GARSHUNI IN THE EDUARD SACHAU'S COLLECTION (THE ONE HUNDRED SIXTY SECOND STORY OF ARABIAN NIGHTS]}

\section{ABSTRACT}

According to Jeremias Schamir (1821-1906), Fellihi is an Eastern Syriac (Surat) dialect spoken by the people around Mosul and Ainkawa in Erbil. Jeremias Schamir is a priest who lived in the Mosul area in the 19th century and is the scribal of many Garshuni (the names of foreign language texts written in the Syriac caligraphy) manuscripts. Schamir worked for the German orientalist Eduard Sachau (1845-1930) and copied many of the Fellihi, Arabic and Kurdish (Garshuni) manuscripts and sent them to Sachau. One of these manuscripts, the Sachau 200, is listed in the Collection of Orientalische Handschriften in the Berlin State Library-Prussian Cultural Heritage (Staatsbibliothek zu Berlin-Preußischer Kulturbesitz). This manuscript includes a number of stories, tales, songs and epics along with an Arabic-Fellihi-Kurdish grammatical dictionary. In this work we will work on one of those stories, called Şebê Şêst $\hat{u} D \hat{u}-J i$ Çîroka Hezar Şeb û Şebek, which has been translated from Arabic into Fellihi and Kurdish. This manuscript consists entirely of 66 leaves and the story in question is between leaf $29 \mathrm{v}$ and leaf $33 \mathrm{r}$. With the introduction of this handbook, in this study our aforementioned story has been Latinized as well as updated in the language of today. In addition, this story was compared to Arabic and other modern translations. As a result of this work, a translation from a foreign language into Kurdish which was done in 1883, was published and shared with researchers.

Keywords: Arabic, Fellihi, Kurdish, Garshuni, Translation, Tale, Arabian Nights, Jeremias Schamir, Eduard Sachau, Manuscript. 


\section{DESTPÊK}

Ji gelek berê de seyahet û çûn û hatina di navbera bajar û welatan de bûye adet. Ticaret, perwerde û îbadetên dînî yên weku heccê (hem ji bo mislimanan hem ji bo mesîhî û cihûyan) ji armancên sereke yên van seyahetan bûne (Yazıc1, 2009, 9-11). Gelek kesan serpêhatîyên xwe yên di van seyahetan de derbasî nivîsê kirine. Ji bo wan nivîsaran seyahetname tê gotin. Xisûsen piştî seyahetnameya seyyahê navdar Îbn Battûta ku di sala 1325an de dest bi seyaheta xwe kiribû û nêzî sî salî li gelek welatan geriyabû, nêrîneke cuda li seyahetnameyan hat barkirin. Ew jî digel nasandina dêmena erdnîgarî û keş û hewayê, nasandina mirov, civak, xelk û dab û nerîtên wan welatan bû (Yazıc1, 2009, 10). Seyahetnameyên bi vî rengî her çiqas weku belgenameyên dîrokî hatibin nirxandin jî gelek caran tûşê rexneyan jî bûne ka çima hin malûmat bi çavekî terefgir hatine qeydkirin. Her çiqas ev guman li ser wan seyahetnameyan hebe jî qeyd û zebtên di wan de hê jî girîngiya xwe diparêzin. Bi taybetî ji bo Kurdan ku çanda wan a nivîskî yan gelekî lawaz bûye yan jî bi caran hatine tarûmar û talankirin, qeyd û xebatên seyyahan ên li Kurdistanê bêtir girîngiya xwe nisşanî me daye.

Îcar yek ji van seyyahan bêguman Eduard Sachau (Edwird Zaxway 1845-1930) bûye ku ew li mintiqeyên Kurdnişîn du caran derketiye seyahetê. Yek ji van di sala 1879-80yan de pêk hatîye ku paşê wî gera xwe ya di vê maweyê de bi navê Reise in Syrien und Mesopotamien (Seyaheta Suriye û Mezopotamyayê) di 1883an de çap kiriye û gera xwe ya duyem a ku di 1897-98an de pêk anîye, bi navê Am Euphrat und Tigris (Li Ferat û Dîcleyê) di sala 1900î de çap kiriye (Gottheil, 1931, 106; Avc1, 2020, 35; Weil, 1965, 4-6). Di van gerên xwe de li cihên weku Şam, Heleb, Bîrecîk, Riha, Reqqa, Dêra Zor, Mûsil, Cizîr, Midyat, Mêrdîn, Dîyarbekir û Antakyayê geriyaye û li wan deran bi gelek kesan re peywendî danîye ku yek ji wan jî keşişsekî Siryan ê bi navê Jeremias Schamir (Yeremya Şamîr 1821-1906) bûye. ${ }^{1}$

J. Schamir, ji bo wergera di navbera zimanan de û îstinsaxkirina wan, alîkarîya E. Sachau kiriye. Herwiha J. Schamir werger û mustensîxê çîroka Şebê Şêst û Dî-Ji Çîroka Hezar Şeb û Şebek e ku ev yek wî ji bo me serincrakêştir dike.

Wisa dîyar e ku peywendîya E. Sachau û J. Schamir ji ber profesorîya Sachau ya li ser zimanên semîtîk û rojhilatî tê. Çimkî Sachau piştî xwendina xwe ya lîsans û doktorayê ku li ser zimanên şerqî û Samî bûye, di sala 1869an de li zankoya Vîyanayê dibe profesorê fîlolojîyê. Herwiha ji sala 1876an û pê ve li zankoya Berlin Friedrich-Wilhelm di beşa fîlolojîya zimanên Samî de kar kiriye û di heman wextî de heya sala 1920an di Seminar für Orientalische Sprachen (Enstîtuya Zimanên Şerqî) de birêvebir bûye (Murad, 2004, 422-423; Gottheil, 1931, 106-107; Ziriklî, 1955, 64; Sehab, 1356/1987: 308). Dema ku ew derketiye seyahetê, xwestiye ji bo van kar û barên xwe nivîs, berhem û destxetên Erebî, Siryanî û Kurdî berhev bike û ji bo vê yekê jî xuyaye ku bi hin kesayetên li wan mintiqeyan re peywendî danîye. Jixwe axirî ev werger û destxet bi giştî li Pirtûkxaneya Eyaletî ya Berlînê-Mîrateya Çandî ya Prûsyayê (Staatsbibliothek zu Berlin-Preußischer Kulturbesitz) di nav koleksîyona Destxetên Rojhilat (Orientalische Handschriften) de li ser

1 Jeremias Schamir, kurê Îshaq el-Kermelîsî ye ku ew mensûbê mala Handolayê Kermelîsî ne. Îshaq el-Kermelîsî, piştî wextan dibe Katolîk. Kurê wî Jeremias, alimekî zîrek û entelektûel bû. Jeremias digel zimanê Aşûrîya Modern (Neo-Aramî), Siryanîya Klasîk, Erebî, Kurdî û Îngilizî baş dizanibû û ew heya radeyekê bi Îtalî, Îbranî, Tirkî û Farisî jî dipeyivî. Piştî ku ew ji dêya xwe bûbû, bavê wî ew bexişandibû dêra Katolîk. Ew jî ji ber zîrekîya xwe di bîst û pênc salîya xwe de bûbû namzetê ritbeya kahîntîyê ku ev ritbe nedidane keşeyên ji sih salî biçûktir. Jeremias, di sala 1846an de ji bo tedrîsa li mekteba Katolîk a Mûsilê hat wezîfedarkirin. Piştî ew li Mûsilê di cemaeta Esahîl Karent de bi dawetkarên Meşîxanîyyîn re hevnas bû, ji hêla meseleyên îmanî ve hin endîşe, teredut û qeyranên rûhanî pê re çê bûn. Van dawetkaran, bi dizî nusxeyeke Kitêba Muqedes ya aîdê xwe dane pê da ku bi kitêbên li dêrê re bide ber hev. Vê yekê kir ku teredutên Jeremias di meseleyên îmanî de zêdetir bibin heya ku bû sebeb ji dêrê bireve. Piştî wê Jeremias çûye Mûsilê û li wir ji hêla konsolxaneya Îngilizan ve hatiye pêşwazîkirin û li Mekteba Yaqûbî dest bi tedrîsê kiriye. Ew di sala 1850yan de di bin birêvebirîya Dwight Marsh de weku dawetkar xebitî û unwana Schamir bi dest xist. Di sala 1854an de bû şêwirmendê malî yê Protestanîya Mûsilê ku ew ji aliyê walîtîya Mûsilê ve weku cemaeteke xweser hatibû naskirin. Di sala 1864an de li Dîyarbekirê di Konsolxaneya Îngilizan de şixulî. Wî di sala 1868an de li Wanê weku wekîlê Nestûrîyan kar kir. Ew di sala 1880yan de vegerîya Mûsilê ku wê çaxê oryantalîstan ew der weku navend bo xwe hilbijartibû. Jeremias jî li wir bi destxet û kitêban re mijûl bû. Ew di wê serdemê de bû hevnasê Eduard Sachau û li ser navê wî di navbera salên 1880-1892yan de ji bo Pirtûkxaneya Neteweyî ya Berlînê xebitî. Wî di wê xebata xwe de gelek destxet peyda kiribûn. Qismek ji wan li ber zêde kirin, qismekî bi şêwaza Gerşûnî nivîsîn, hinên kêmpeyda jî wekxwe ji bo Sachau bi rê kirin. Ew di sala 1906an de mir û li Mûsilê li Dêra Mor Sûmak hat definkirin (Tammu, 2012; Ebied \& Al-Jeloo, 2010, 1-7). 
navê wî (Sachau) hatine qeydkirin. Destxet û wergera ku em ê di vê xebatê de binirxînin, di nav vê koleksîyonê de di bin navê Sachau 200 de hatiye qeydkirin (Digitale Bibliothek der SBB, 2021).

Koleksîyona Eduard Sachau ya li Berlînê parastî, ji hêla naveroka xwe pir zengîn e. Di warê teolojî, zimannasî, edebîyat û berawirdkarîyê de destxetên girîng tê de parastî ne. Nêzî $150^{2}$ destxet li ser navê wî qeydkirî ne (bnr. Digitale Bibliothek der SBB, 2021). ${ }^{3}$ Ev destxet piranî bi zimanê Erebî û Siryanî ne. Hin ji wan bi tîpên Erebî hatine nivîsîn û hin ji wan jî bi tîpên Siryanî hatine nivîsîn. Xala herî balkêş jî ew e ku hin ji van destxetan bi zimanê Kurdî, lê bi alfabeya Siryanî ne ku ev destxet bi navekî taybet tên binavkirin ku ew jî "Gerşûnî" ye. ${ }^{4}$ Di nav koleksîyona wî de destxet û xebatên li ser ziman û edebîyata Kurdî hene ku di warê wergerê de ango wergera ji Erebî û Siryanî bo Kurdî qîmeteke xwe ya din heye. Çimkî di wan salan de wergera Kurdî hêj ewqas ne di rewacê de bû û kesî guh nedidayê. Loma hebûna çend destxetan a di vî warî de, bo ziman û wergera Kurdî bê şik dê hin fikir û nêrînan bide lêkolîneran. Di nav xebatên Kurdî yên vê koleksîyonê de destxetek bi navê Sachau 250 heye ku ev ferhengeke Îngilizî-Fellîhî(Siryanî)-Kurdî ye. Ev destxet ji xebata Faris el-Shidiac hatiye wergerandin (el-Shidiac, 1856, 117-148). Destxeteke din bi navê Sachau 204 hatiye qeydkirin ku ev lawijên Kurdî yên dînî ne û ji alîyê Mifiryanê Tora Abdîn, Basilyos Şemûnê Duyem ve hatine gotin û di kovara Hawarê hejmara 25an de bi navê Lavij ji hêla Celadet Alî Bedirxan ve Kurdîya wê ya latînî û wergera wê ya Fransî digel hev hatine belavkirin (Bedirxan, 1934; Azîzan, 1941). ${ }^{5}$ Ji bilî vê, çar destxetên Mem û Zîna Ehmedê Xanî tê de bi navê Sachau 320, Sachau 341, Sachau 342 û Sachau 344 qeydkirî ne ku digel Kurdî wergera Mem û Zînê ya Erebî jî di nav de heye. Herwiha keşkûleke ku bi navê Sachau 200 hatiye qeydkirin, di koleksîyonê de cih digire û çîroka Şebê Şêst $\hat{u}$ Dû-Ji Çîroka Hezar Şeb û Şebek, beşek e di nav vê keşkûlê de (bnr. Digitale Bibliothek der SBB, 2021).

Em ê di vê gotarê de bala xwe bêtir bidin vê destxetê (Sachau 200) û xisûsen jî çîroka Şebê Şêst $\hat{u}$ Dû-Ji Çîroka Hezar Şeb û Şebek. Em ê hem bi zimanê Fellîhî ${ }^{6}$ hem jî bi zimanê Kurdî latînîze bikin û van her du metnan digel metna resen a Erebî ku di berhema Faris el-Shidiac (1856, 52-67) de ye û digel wergerên Soranî, Tirkî û Farisî berawird bikin û nirxandineke berawirdî li ser vê çîrokê nîşan bidin. Di vê nirxandinê de em ê bêtir li ser wergera metnê hûr bibin ka bi çi şikilî hatiye wergerandin ji bo Kurdî. Berî ku em derbasî vê nirxandinê bibin, em ê qala çemka "Gerşûnî” bikin û paşê li gorî rêbaza nasandina destxetan a ku Margarita Borisovna Rudenko (1961) ji bo Danasîna Koleksîyona Destxetên Kurdî yên li Lenîngradê kiribû, destxetê û beşa çîrokê bidin nasandin. Axirî em ê nusxeyên resen û latînîzeya qismê çîroka Şebê Şêst û Dû-Ji Çîroka Hezar Şeb û Şebek di pêveka gotarê de daînin û bi vî şikilî gotarê bi encam bikin.

\section{GERŞÛNî Û GERŞÛNÎYA KURDî}

Li ser koka peyva Gerşûnî îdiayên ciyawaz hene. Ya herî zêde berqebûl ew e ku ji koka lêkera graş (siخ) a Siryanî darijîye. Wateya peyvî ya "graş"ê (siخ) "kişandin", "qetandin", "dirêjkirin" an jî “xapandin" e (Bulut, 1996, 63). Gerşûnî di çavkanîyan de weku "nivîsandina metnên Erebî bi alfabeya Siryanî" an jî "bikaranîna tîpên Siryanî ji bo her tîpeke peyvên ku bi Erebî tên xwendin" hatiye pênasekirin. Lê paşê ev pênase hatiye berfirehkirin ku ji bo her metneke zimanekî biyanî ya ku bi tîpên Siryanî hatiye nivîsandin,

2 Me 146 destxetên li ser navê wî qeydkirî di vê koleksîyonê de tesbît kirin. Lê ev ne hejmareke teqez e. Lazim e ev bi lêkolîneke berfireh bê piştrastkirin.

3 Herwiha heke hûn bixwazin bigihêjin bîblîyografyaya xebatên Eduard Sachau û bi giştî bibînin ka çi xebat pêk anîne, ji kerema xwe li vê berhemê binêrin: (Weil, 1915, 1-14).

4 Gerşûnî: Navê metnên zimanê bîyanî ne ku bi alfabeya Siryanî hatine nivîsîn (Ergin, 2011, 418; Direkçi, 2018). Em ê di vê xebatê de bi berfirehî qala wê bikin.

5 Herwiha xebateke din ji hêla Wedî’ Dûşî ve bi navê el-Lawîc; Teratîl Enşedha el-Mifriyan Mar Basîliyos Şemû'n elSanî hatiye kirin ku wî digel xetên resen, bi tîpên erebî Kurmancîya lawijê û wergera wê ya Erebî nivîsîye û derbarê Basilyos Şemûnê Duyem de hin agahî dane (bnr. Dûşî, 1996).

6 Fellîhî devokek an zaraveyekî zimanê Siryanîya rojhilat (Sûrat) e ku li gorî Jeremias Schamir, ew ji aliyê şênîyên li devdora Eynkawaya Hewlêrê û mintiqeya Mûsilê ve tê axaftin. Schamir, di destxeta Sachau 200 de li du cihên cuda de wiha qala Fellîhî kiriye: "Fellîhî, zimanekî devera gundê Eynkawayê ya li ser Hewlêrê ye ku ew dikeve navbera Mûsil û Bexdayê. Ev ziman şubhê zimanên Teyyarî ye ku ew ji Tora Mêrdînê ta sînorê Ecema Îranê berbelav in.” (Schamir, 1883, wr. 28v). Ew li dereke din jî wiha dibêje: "Çawa ku zimanê Kurdî ji Farisî darijî be, zimanê Fellîhî jî wecheke din ê zimanê Siryanî ye. Fellîhî weku zimanê Siryanî, ji zimanê kevin ê Aramî darijîye.” (Schamir, 1883, wr. 58r). 
"Gerşûnî” hatiye gotin. Paşê kesên weku George Kiraz, Andrea Schmidt, Johannes den Heijer û Tamar Pataridze maneyên berfirehtir li vê peyvê bar kirine (bnr. Kiraz, 2012, 291; 2014, 65-75). Piştî hatina Îslamê li hêla Kurdistanê û deverên Siryanînişîn, peywendîya van miletan bi Erebî re çê bû û Kurd û Siryan jî Erebî hin dibûn û diaxivîn. Ji ber ku nivîs li cem Siryanîyan berê jî xurt bû, adetekî wisa çê bû ku metnên Erebî yan jî gotin û peyvên Erebî bi tîpên Siryanî hatin nivîsîn û ji bo hin dengên xerîb hin sembolên din hatin afirandin û bi vî şikilî metnên Gerşûnî peyda bûn. Helbet heya sedsala 14an metnên Gerşûnî bi piranî metnên kurt an jî hin nivîsên basît bûn. Lê pê da pê da bi taybetî piştî sedsala 15an û xisûsen jî di navbera sedsalên 17 û 19an de metnên dirêj û her cure nivîs bi şêwaza Gerşûnî dihatine nivîsandin û weku adetekê ev berbelav bû.

Li gorî zanyarîyên li ber destan, metnên Gerşûnî yên Kurdî cara ewil di sala 1740an de bi lawija Mifiryanê Tora Abdîn Basilyos Şemûnê Duyem hatine dîtin. Paşê bi taybetî bi hatina mîsyoner û oryantalîstan a li Kurdistanê, hebûna van metnan zêde bûye. Çimkî wan xwestiye Kurdan nas bikin û bi rêya kesayetên Siryanî yên li deverê metnên bi vî rengî dane nivîsandin an jî çi metnên bi vî rengî hebin berhev kirine û li pirtûkxaneyên welatên xwe parastine. Ji bilî van di arşîvên gelek dêr û keşîşxaneyên li Kurdistanê jî metnên bi vî rengî peyda dibin. Mesela di pirtûkxaneya Dêru'l-Zeferanê de, di Koleksîyona Destxetên Rojhilatî yên li Pirtûkxaneya Neteweyî ya Berlînê, di Koleksîyona Dawid Barazne (1820-1880) ya li Kitêbxaneya Keşişxaneya Mor Yaqûb a li Mûsilê de, di Koleksîyona Destxetên Rojhilatî ya li Kitêbxaneya Îngilistanê de, di Sazîya Çand û Berhemên Qedîm a Iraqê de metnên Gerşûnî yên Kurdî mewcûd in (Ergin, 2011, 417 445; Dinno, 2014, 195-213; Dehqan \& Mengozzi, 2014, 53-79; Harrak, 2010, 737). Bêguman Sachau 200 jî yek ji van destxetan e ku em ê li jêr bidin nasandin û paşê derbasî qismê wergera Erebî-Fellîhî-Kurdî ya çîroka Şebê Şêst û Dû-Ji Çîroka Hezar Şeb û Şebek bibin.

\section{NASANDINA DESTXETÊ}

Nimreya Arşîvê: Sachau 200 (PPN: 871612011)

Zimanê Destxetê: Siryanî (Fellîhî), Kurdî û Erebî.

Mijara Destxetê: Ziman, Vegêran, Dîn.

Alfabeyên Destxetê: Alfabeya Erebî û Alfabeya Siryanîya Rojhilat.

Navê Nivîskar: Beşên di destxetê de bi piranî berhemên anonîm in. Lê ferhengoka Erebî-Fellîhî-Kurdî ji kitêba Faris el-Shidiac ji hêla Jeremias Schamir ve hatiye wergerandin.

Navê Berhemê: Berhemeke yekpare nîne. Ev destxet weku keşkûlekê ji neh beş û berhemên cuda pêk tê. Berhem weku keşkûl bi vî navî hatiye binavkirin: Materialien für das Studium des Fellihi und Kurdisch, Geschichten, Mitteilungen über Jeziden und die Ostsyrer (Hin materyal ji bo xebatên li ser Fellîhî û Kurdî, Hîkayet û Pendên derbarê Êzidî û Siryanîyên Rojhilatî).

Qeyda Temetê: Mustensîx ji bo her beşekê, qeyda temetê cuda danîye. Wî di van qeydan de bêtir qala naveroka wê beşê û şêwaza xebata xwe kiriye. Yanî xisûsî qala sal, meh û mustensîx nekiriye. Çimkî J. Schamir bixwe hemû beş di sala 1883an de îstinsax kirine. Lê di beşa yekem a destxetê de di wereqên $28 \mathrm{r}-28 \mathrm{v}-29 \mathrm{r}^{7}$ de em dibînin ku J. Schamir îmzeya xwe xêz kiriye û herwiha cihê îstinsaxê (Mûsil) û tarîxa îstinsaxê (1883) dîyar kiriye.

Dîroka Îstinsaxkirinê: Piştî Zayînê 01.01.1883-31.12.1883. Wisa xuyaye di nav salekê de hatiye temamkirin.

\section{Cihê Îstînsaxkirinê: Mûsil.}

Zanyarîyên li ser Berga Ewil: Li ser bergê tu zanyarî tuneye.

7 Herfên ku me li cem hejmara wereqan (wr.) weku " $r$ " û "v" nîşan dane ji bo dîyarkirina rûpelan e. Herfa " $r$ "yê di wereqê de milê rastê nîşan dide û herfa "v"yê jî di wereqê de milê çepê nîşan dide. Di kataloga destxetê de jî ev wisa hatîye destnîşankirin. Em jî li gorî wê tevgerîyan. Binêrin: https://digital.staatsbibliothek-berlin.de/werkansicht?PPN=PPN871612011\&PHYSID=PHYS_0025 
Zanyarîyên li ser Berga Dawî: Li ser bergê ji bilî logo/sembolek tu zanyarî tuneye. Ev logo jî di nîveka bergê de bi vî rengî ye:

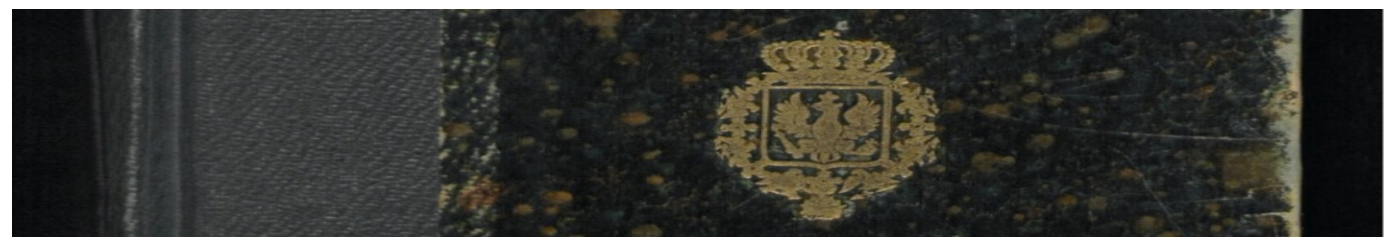

Taybetîyên Bergê: Berg ji karton û çerm hatiye çêkirin û bi rûpelan ve hatiye dirûtin. Xuyaye ku bergekî hişk e û rengê wî reş û gewr têkel e.

Taybetîyên Kaxezê: Kaxezên destxetê zerekî sayî ye. Dîyar e ku kaxezên zirav in.

Jimara Wereqan: Ev destxet bi tevahî ji 66 wereqan pêk tê. Tu nivîs di 10 wereqên ewil de nehatiye nivîsîn ango vala ye.

Jimara Rûpelan: Her du berg ne tê de, bi tevahî ji 136 rûpelan pêk hatiye. Piştî berga ewil û berî berga dawî ji wereqan nehatîye hesibandin û weku kaxezên vala hatine hesabkirin.

Jimara Stûnan: Piştî wereqên vala ji wereqa 11 an heya wereqa 33 an yanî beşa ku weku ferhenga Erebî-Fellîhî-Kurdî hatiye nivîsîn, her rûpel dabeşî sê stûnan bûye û wereqên mayî hemû yek stûn in.

Jimara Rêzan: Di her rûpelê de jimara rêzan ne standart e. Lê bi giștî di her rûpelê de jimara rêzan di navbera 32 heya 37 an diguhere.

Rengê Murekebê: Tenê rengê reş hatiye bikaranîn.

Hecma Wê: 30x10 cm ye.

Zanyarîyên Derkenarê: Zêde zanyarî li derkenarên destxetê nînin di beşa yekem de çend zanyarî bi zimanê Erebî dixuyên û carinan di navê re di hin wereqan de bi vî teherî xuya dikin:

\begin{tabular}{|c|c|c|}
\hline Latînîze û wergera wê ya Kurmancî & $\begin{array}{l}\text { Hejmara } \\
\text { wereqê }\end{array}$ & $\begin{array}{l}\text { Zanyarîyên derkenarê bi halê } \\
\text { xwe yê resen }\end{array}$ \\
\hline $\begin{array}{l}\text { "Nuqtetun kubra 'ala Bê tesîru Vê" (Heke xaleke mezin bê ser } \\
\text { herfa "Bê" ew dibe dengê herfa "V") }\end{array}$ & wr. 11r & نقطة كبرى على بي تصير ثى ( ذ) \\
\hline $\begin{array}{l}\text { "Nuqtetun 'ala Şîn tesîru Jê" (Heke xal bê ser herfa "Şîn” dibe } \\
\text { "Jê") }\end{array}$ & wr. 11r & نقطة على ش تصير زى ( غ ) \\
\hline "Mîmun mufeḩhemetun" (Mîma Stûr) & wr. $11 \mathrm{r}$ & ميم مفخمة \\
\hline Katib-Niwiswer (Nivîskar) & wr. 11r & كاتب ـ نويسور \\
\hline $\begin{array}{l}\text { "Beyne muzekkerin li muennesin bi'l-Kurdî ma yûcedu ferqun } \\
\text { illa nadirun" (Ji bilî hin rewşên awarte di Kurdî de ferqa nêrtî û } \\
\text { mêtîyê nîne) }\end{array}$ & wr. $11 \mathrm{r}$ & 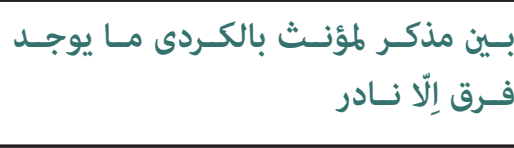 \\
\hline $\begin{array}{l}\text { "Enva‘u funûni’l-mevcûdetî bi luğeti'l-'arabiyyetî ma yûcedu } \\
\text { bi’s-Suryanî we Kurdî li eclî zaalike ihteșerna 'ala qederi’l-imkanî } \\
\text { ketebna mîmma yumkînu” (Hin hunerên di Erebî de hene di Sir- } \\
\text { yanî û Kurdî de nînin. Ji ber vê egerê li gorî derfetên xwe me hin } \\
\text { qaîde bi awayekî kurt û xas nîșan dan û nivîsîn) }\end{array}$ & wr. $11 \mathrm{r}$ & 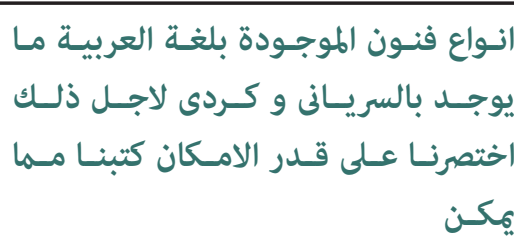 \\
\hline
\end{tabular}

Destpêka Destxetê: Ji wereqa 11r dest pê dike ango bi beşa yekem dest pê dike ku di vê beşê de her sê ziman ji hêla hin navdêr û peyvan ve hatine berawirdkirin. Ya rastî Jeremias Schamir ew navdêr û peyv ji Erebî wergerandine Fellîhî û Kurdî. Ji bo mînakan bala xwe bidin çarçoveya jêrîn: 


\begin{tabular}{|c|c|c|c|c|c|}
\hline \multicolumn{2}{|c|}{ 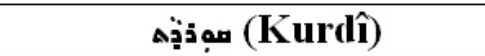 } & \multicolumn{2}{|c|}{ صفذَّه (Fellîhîi) } & \multicolumn{2}{|c|}{ جذَّب } \\
\hline $\mathrm{Nab}$ & تذ & Sumā & raxäs & İsmun & اسم \\
\hline Nêr & يذٍ & Urzā & 2 & Muzekkerun & مذكر \\
\hline Mêh & مِيَّة & Nêqwā & يمة' & Muennesun & مؤنث \\
\hline Jimartin & تفبذفي & Menyānā & مِينتخ & 'adedun & عدد \\
\hline Malan/Kan & 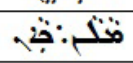 & Bātê & تيني & Buyutun & بيوت \\
\hline Dû Malan & جִּ فتثم & Trê Bātê & Aي & Beytani & بيتان \\
\hline Mal & ت135 & Bêtā & 䒚 & Beytun & بيت \\
\hline Niwîskeran & يمبعجذٍ & Katāwê & خجتِقِة & Katibune & كاتبون \\
\hline Dû Katiban & 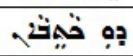 & Trê Katāwê & 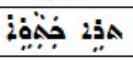 & Katibani & كاتبان \\
\hline
\end{tabular}

Dawîya Destxetê: Ev jî bi wereqa 66r xelas dibe. Agahîyên derbarê beşa nehan de bi ziman û tîpên Siryankî (Fellîhî) hatine nivîsîn.

\begin{tabular}{|c|c|c|}
\hline $\begin{array}{l}\text { Ktululî ādî hụukîtā b-Qurdāt } \\
\text { Mturcmâlî min 'arabî. ilādāk } \\
\text { Āmrin b-dāyêlā w-la-k-țāyāwā d-hāwnā } \\
\text { Mturcāmtā ilā katịir dê-lyāfā } \\
\text { Lušānā d-Qurdāyê d-yalî dun b-nāšê }\end{array}$ & 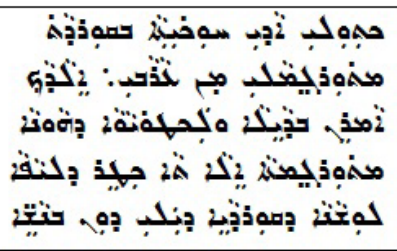 & $\begin{array}{l}\text { Fellihịi } \\
\text { Herî } \\
\text { Dawî } \\
\text { Wr. 66r }\end{array}$ \\
\hline $\begin{array}{l}\text { Maneya Wê: "Ev hîkayeta nivîsandî, mir } \\
\text { karekî beredayî û ne hêjayî wergêranê ye. } \\
\text { binîya însanan re ne." }\end{array}$ & u Ieri zimane & \\
\hline
\end{tabular}

Beşên Destxetê: Ev destxet weku keşkûlek/antolojîyek ji komija 9 berheman pêk tê. Em ê li vir bi kurtî qala her beşê bikin û paşê qismê ku Şebê Şêst û Dh-Ji Çîroka Hezar Şeb û Şebek tê de cih digire bidin nasîn:

Beşa yekem: Di navbera van wereqan (wr. 1-33r) de bi cih bûye. Di vê beşê de mînakên peyv û dîyalogan û hîkayetên di berhema Faris el-Shidiac de ku li ser pratîka gramera Erebî ye û bi navê A Practical Grammar of the Arabic Language di sala 1856an de li Londonê çap bûye, hatine wergerandin ji bo zimanê Fellîhî (lehçeya Eynkawa ya Siryanî) û Kurdî (lehçeya Hekarî ango Badînanî). Ji wereqa lan heya wereqa 10an kaxezên vala hene ango tiştek nehatiye nivîsîn. Di navbera wereqên (11r-28r) de ferhengeke Erebî-Fellîhî-Kurdî hatiye amadekirin ku ev jî di nav xwe de bûye du qisim; qismê yekem ji wereqa 11r heya wereqa 16v dewam dike ku ev mînakên navdêr, hejmarnav û peyvên din ên ziman in û qismê duyem ji wereqa 16v dest pê dike heya wereqa $28 \mathrm{r}$ didome ku ev jî mînakên dîyalogên rojane ango sereke yên bi her sê zimanan dihewîne. Herwiha ji wereqa 28v heya wereqa 33r wergera du hîkayetan cih digire ku hîkayeta ewil, di navbera wereqa 28v-29r de ye û hîkayeta duyem ku weku çîroka Şebê Şêst $\hat{u}$ Dû-Ji Çîroka Hezar Şeb û Şebek hatiye binavkirin; di navbera wereqên 29v-33r de cih digire. Her du hîkayet jî rûpelek bi Fellîhî nivîsîye û rûpela li dû wê bi Kurdî wergerandiye. Van her du wergeran jî li ber ya Erebî zêde kiriye ku di berhema Faris el-Shidiac de mewcûd in (el-Shidiac, 1856, 49-67).

Beşa duyem: Di navbera wereqên 33v-37r de bi cih bûye. Ev beş kopyayeke nameya derbarê parastina Xiristîyanên di serdema Hz. Muhemed de ye. Li gorî J. Schamir, Hz. Muhemed ev weku nameyekê di 4emîn sala Hicrî û roja 5an a meha Rebîul Axir de ku dibe roja duşemê, bi Mûawîye daye nivîsandin. J. Schamir di wereqa 37r de wiha dibêje: "Min ev ji ber destxeteke ku li ser parşomen û çermê xezalê hatibû nivîsandin, zêde kir. Misilman vê weku nivîseke pîroz qebûl dikin, lê gotinên wê bi cih naînin. Min xwest wê destxetê bikirim, lê nefirotine min. Loma min ev nusxe li ber zêde kir." (Sachau 200, 1883, wr. 37r). Ev beş Erebî ye û qismekî piçûk bi Fellîhî hatiye nivîsîn.

Beşa sêyem: Di navbera wereqên 37r-39r de bi cih bûye. Ev beş derbarê pêşkêşkirina Êzidîyên Dasenê bo hikûmeta Tirkan e. Yanî ji bo xizmetguzarîya artêşa mureteb a Tirkan, pêşkêşkirina leşkeran e. Bi 14 xalan, nemimkûnîya vî karî tê ravekirin. Bi ziman û alfabeya Erebî hatiye nivîsîn.

Beşa çarem: Di navbera wereqên 39v-42r de bi cih bûye. Dab û nerît, esasên ayîna Ezdîyatîyê û hin 
îqtibas ji pêşengê wan Şêx 'Adî û danasîna wî di vê beşê de hatine nivîsîn ku ev agahî ji kronîka Mûsilê ya Muhemmed Emîn Îbn Xeyrullah hatine vegirtin. Bi ziman û alfebeya Erebî hatiye nivîsîn.

Beşa pêncem: Di navbera wereqên $42 \mathrm{v}-43 \mathrm{v}$ de bi cih bûye. Ziman Siryanîya kevin e. Hin îqtibasên ji kitêba hîkayetan a Bar Hebraeus tê de ne. Bar Hebraeus an jî bi navê xwe yê din Ebu'l-Ferec Îbnu'l-'Ibrî (1225-1286), Katolikosê Siryanî ye ku di sedsala 13em de li Meletîyê hatiye dinê (Özaydın, 2000, 92-94).

Beşa şeşem: Di navbera wereqên 44r-47r de bi cih bûye. Çend helbestên Kurdî di vê beşê de hene. Sîstema nivîsîna helbestan bi vî rengî ye; rêzikek Kurdî, rêzikek Erebî. Yanî pêşî Kurdîya helbestê paşê wergera wê ya Erebî danîne binî. Qismê Kurdî bi alfabeya Siryanî hatiye nivîsîn û qismê Erebî jî bi alfabeya Erebî hatiye nivîsîn. Ev helbest derbarê destana Sîyabend $\hat{u}$ Xecê û Genc Xelîl de ne. Qismek ji dawîya destana Sîyabend $\hat{u}$ Xecê û qismek jî ji serborîya Genc Xelîl tê de ye.

Beşa heftem: Di navbera wereqên 47v-58r de bi cih bûye. 92 kilam di vê beşê de hene ku ev bi devoka Telkefê (Tilkîf) ${ }^{8}$ ya Fellîhî hatine nivîsîn. Ev kilam her yek ji wan ji 3, 4 an zêdetir rêzikan pêk tên û her kilam di nav xwe de bi serwa ye. Ev kilam, yên populer bûne ku di dawet, govend û cejnan de hatine strandin. Bi alfabeya Siryanî hatiye nivîsîn.

Beşa heştem: Di navbera wereqên 58v-63v de bi cih bûye. Hîkayeta Duennayê, hîkayeteke qehremanîyê ye. Li ser hîkayeta mîrzayekî ciwan û tercumanê wî ye. Bi ziman û alfabeya Erebî hatiye nivîsîn.

Beşa nehem: Di navbera wereqên 63v-66r de bi cih bûye. J. Schamir, di vê beşê de derbarê Siryanîyên rojhilatî û xisûsen yên çîyayî de hin agahî nivîsîne. Wî derbarê kok û eslê wan, tarîxa wan û hal û rewşa wan de çend tişt nivîsîne. Bi ziman û alfabeya Erebî hatiye nivîsîn.

\section{Qismê Çîroka Şebê Şêst û Dû-Ji Çîroka Hezar Şeb û Şebek di nav Beşa Yekem a Destxetê de (wr. 29v-33r)}

Destpêka Çîrokê: Ji wereqa 29v dest pê dike. Ji ber ku Jeremias Schamir çîrok ji Erebî bo Fellîhî û Kurdî wergerandîye, li hêleke wereqê Fellîhî danîye û li hêleke din a wereqê Kurdî danîye. Yanî rûpelek bi Fellîhî rûpelek bi Kurdî dewam kiriye. Loma em ê hem destpêka çîrokê bi Fellîhî hem jî bi Kurdî li vir parve bikin. Herwiha Kurdîya çîrokê jî ji wereqa 30r dest pê dike.

\begin{tabular}{|c|c|c|}
\hline $\begin{array}{l}\text { Lêlê d-Emā w-etrê w-êştî } \\
\text { Men qiṣetā d-elfā lêlê w-lêlê }\end{array}$ & 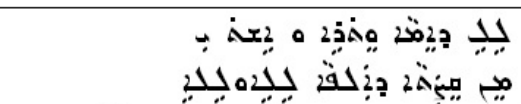 & \multirow{2}{*}{$\begin{array}{c}\text { Fellihịi } \\
\text { Serî }\end{array}$} \\
\hline $\begin{array}{l}\text { Kûd hwêlê lêlê kininā. Mêrā Dînāzad li knātāh } \\
\text { Şehirzād. Ya kāâtî, Ên liwat d-mêkm } \\
\text { Mitemim țalên hûkîntā }\end{array}$ & 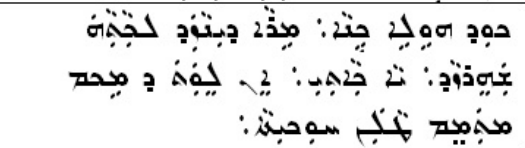 & \\
\hline $\begin{array}{l}\text { Şeb̂ê Șed û Şêst û Dû } \\
\text { Ji Çîroka Hezar Şeb û Šebek }\end{array}$ & 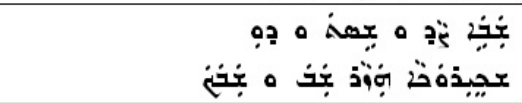 & \multirow[t]{2}{*}{$\begin{array}{l}\text { Gerşûnî } \\
\text { Serî }\end{array}$} \\
\hline $\begin{array}{l}\text { Hingî bû şebêe ê dî: Got Dînazad li huşskê } \\
\text { Şehirzad: herê hûş̧ka: heka tû nerazay } \\
\text { Temam bika bo ma çîrok. }\end{array}$ & 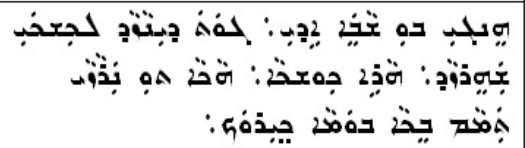 & \\
\hline
\end{tabular}

Dawîya Çîrokê: Dawîya çîrokê ya qismê Fellîhî bi wereqa 32v diqede û qismê Kurdî bi wereqa 33r diqede ku me li jêr nîşan dane.

\begin{tabular}{|c|c|c|}
\hline $\begin{array}{l}\text { Wêwā b-dûktā 'lîtā } \\
\text { Men er'ā b-wiŝlê êlêd er'āa } \\
\text { w-pişlê tịwîkāâ d-îbêê }\end{array}$ & 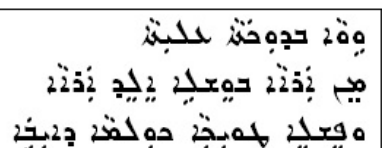 & $\begin{array}{l}\text { Fellihi } \\
\text { Dawî }\end{array}$ \\
\hline $\begin{array}{l}\text { bi çêh hawras bûn } \\
\text { ji 'ardê hat nişî̉b li 'ardê } \\
\text { û gişt şikesta hemî di tê da bû }\end{array}$ & 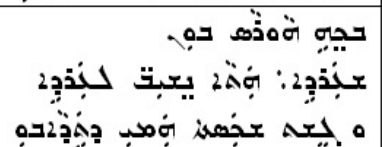 & $\begin{array}{l}\text { Gerşûnî } \\
\text { (Kurdî) } \\
\text { Dawî }\end{array}$ \\
\hline
\end{tabular}

8 Telkef (Tilkîf): Gundekî mezin ê Xiristîyannişîn (Siryan) e ku ji hêla bakurrojhilatê Mûsilê ve 8 km dûrî Mûsilê ye (ishtartv, 2011). 
Naveroka Çîrokê: Çîrokên Hezar Şev û Şevekê ji hin efsane û hîkayetên Îranî (Hezar Efsane) hatine afirandin û di sedsala 13 an 14an de ji bo Erebî hatine wergerandin û nivîsandin û bi vî şikilî di nav gelek ziman û miletan de belav bûye. Ev berhem bi tevahî ji 264 çîrokan pêk tê ku hin çîrok di çend şevan de li ser hev hatine vegêran û bi vî şikilî vegêrana çîrokan bi temamî di hezar û yek şevan de qedîyaye. Karakterên sereke yên berhemê Şah Şehrîyar û jina wî Şehrazad in. Li gorî berhemê piştî ku jina ewil a Şehrîyar ew bi hin kesên din dixapîne, Şehrîyar lê dixe jina xwe dikuje û ji wê rojê şûnde bawerî bi jinan naîne û li ser vê ji wezîrê xwe dixwaze ku her şevê jê re jinekê bîne û piştî ku pê re wext derbas kir, wê bikuje. Ev adet heya Şehrazada keça Wezîr didome. Lê piştî ku şevek Şehrazad ji Şehrîyar re tînin, Şehrazad biryar dide ku xwe bi saya çîrokbêjîyê ji mirinê xelas bike û wisa dike ku çîrok di nav çîrokê de hezar û yek şev li ser hev ji Şehrîyar re çîrokan vedigêre. Bi vî rengî di dawîya şeva hezar û yekê de Şehrîyar dibe aşiqê Şehrazadê û zarokekî wî jê çê dibe û bi wî şikilî Şehrazad ji mirinê xelas dibe. Du karakterên din ên girîng jî di nav van hîkayetan de hene ku yek jê Wezîrê Şehrîyar û a din jî carîye ango xizmetkara Şehrazadê, Dînarzad e. Gelek wergerên vê berhemê bo zimanên ciyawaz çê bûne û herwiha vê berhemê tesîr li vegêrana modern kiriye ku ji hêla vegêrana çîrokên çarçoveyî ango çîrok di nav çîrokê de weku şaheserek tê pejirandin (Nicholson, 1907, 456-459; Nicholson, 2007, 307-310; Al-Muqaffa, 1935; Tesûcî Tebrîzî, 1389/2011; Daraxa, 2015; Onaran, 1992; Gemi, 2016).

Çîroka ku babeta vê xebata me ye, çîroka di şeva sed û şêst û duyan de ye ku ji Erebî bo Fellîhî û Kurdî ji hêla Jeremias Schamir ve di sala 1883yan de ji kitêba Faris el-Shidiac (1856, 52-62) hatiye wergerandin. Ev çîrok weku çîroka birayê sertiraş (berber) hatiye binavkirin ku rêzeçîrokeke ji devê Sertiraş tê vegêran. Di nav vê rêzeçîrokê de çîroka me ya navborî derbarê serborîya birayekî sertiraş (birayê pêncem) de ye. Esil ew heft bira ne û di nav wan de birayê pêncem an jî di hin nusxeyan de birayê bi navê el-Aşar, 100 dîrhemê ku ji bavê wî jê re mîras mayî, pê şûşeyan dikire. Paşê diçe li meydanekê, li ber dîwarekê radiweste da ku wan şûşeyan bifiroşe. Di wê esnayê de dikeve nav xeyalan ku bi van 100 dîrhemên xwe dê çawa ticaretê bike û zengîn bibe ta ku di dawîya xeyala xwe de pêyên xwe bi şaşitî li selika şûşeyan dixe û hemûyan dişikîne (Schamir, 1883, wr. 29b-33a). Di destxeta me de çîrok heya vir didome û paşê xelas dibe. Lê di eslê xwe de piştî vê jî çîrok dewam dike heya ku el-Aşar dikeve destê dizan, tolhildana wî ji dizan, danûstandina wî û walîyê bajêr û ta ku poz û guhên wî tên jêkirin (Al-Muqaffa, 1935, 101-102; Tesûcî Tebrîzî, 1389/2011, 138-142; Daraxa, 2015, 210-214; Onaran, 1992, 152-165). Di wergera Schamir de qutbûna çîrokê ji nîvî, helbet ji ber metna resen e. Çimkî di wê metnê de çîrok hewqas hatiye neqilkirin. Bî îhtîmaleke mezin qutbûna vê çîrokê ji ber kutabûna şeva sed û şêst û duyem e. Nusxeya ku el-Shidiac çîrok jê wergirtî, di bin sernavê şeva sed û şêst û duyan de bi vî şikilî diqede ku di wergerên Fellîhî û Kurdî de jî wisa bûye. Çimkî em li hin wergerên din jî binêrin (Daraxa, 2015, 207-209) em ê bibînin ku ev çîrok di şeva sih û duyem de hatiye vegêran û dema şev kuta bûye, çîrok jî li wir qut bûye û qismê mayî yê çîrokê di şeva sih û sêyem de dewam kiriye û qiseta birayê pêncem gihiştiye encamê (Daraxa, 2015, 210-214). Weku vê rewşê mimkûn e çîroka ku Schamir wergerandîye Fellîhî û Kurdî di şeva sed û şêst sêyem de dewam kiribe û gihiştibe encamê. Lê ji ber ku li ber destê me nîne û di nav destxeta me ya navborî de ew qisim nîne, em ê li dû dûmahîka çîrokê nekevin.

\section{DESTXETA ORJÎNAL Û TRANSKRÎPSÎYONA WÊ}

Ev transkrîpsîyon ji hêla me ve hat kirin û ji bo ku di çapê de xerab nebe, me ew bi mecbûrî li vir di formata wêneyan (JPEG) de parve kirin. Ji ber ku metna Fellîhî li gorî devoka Siryaniya rojhilat hatiye nivîsîn me jî transkrîpsîyona Fellîhî li gorî wê devokê kiriye. Herwiha di transkrîpsîyona Kurdî-Gerşûnî de me di hin dengan de li gorî Kurdîyê hin guherîn kirine. 


\section{Wr. 29v}

\section{䒿 \\ LÊLÊ D-IMĀ WI-TRÊ W-TÊS̆TÂ MIN QIȘATÊ D-ALFĀ LÊLÊ W-LÊLÊ}

Kud hwêlê 1êlê ǩênā, mêrā Dînāzad, 1-knātāh Šahirzād. Ya Katî, in lêwat d-miknyā Mitamim țālan hukîtā. Mêrā țālāh Hawā kabîrā. šmilî yā malkā migubțā Digrā'ā mêrê. w-akconî d-ḳ̌āmšā hawā yatyātêh qițiê. w-gorā mêskênêwā gāwêwā mināšê b-1êlê w- 'ayišwābay gāway b-yomā. wê-mhaslānan sāwā wê-wā rābā iwîrā b-šine. B-rihlê $w$-mițlê pišle bātrêh šā' à imê dêrhāmê mfûlîlan bênātā̄n wê-šqilê kûd ḳ̌āmšā šqîlîlê darhāmê ilā aḱnonî d-ǩāmšā šqîlilie dirhāmê w-hrêbay w-laydelê mā āwidbay w-kûrîwā mtaǩmālê b-ānî zûzê. Têlê 1-ḅālêh d-zāhinbay šûše d-kul šikil wi-mzabinî wi-mhāșilbay. Zwinê šûše wi-drêlê b-saltāa rabtāa w-tûlê b-dûkțā di-mzāạin minay wi-bodifnêh itwāa gûdā tkêle kāasêh ileh w-tûlê li-mtakmālê. W-mirê bigyānêh. idā yā gyānî rišmālî d-ādî šûše mzaḅnênûn $b$-arbamā darhāmê aygā lagbațlin mizwānā w-zābāanê hil d-hāwê 1-gêbîi arḅāa alfê dirhamê wi-ḅzānên ḅ̂i sileztā w-mațininā 1-dûktā hādāk. We-mzaḅnenā betmanyā alfe dirhamê. W-aygā lagbațlin mizwānā slintā kididā gāway d-hāwêbay min kûl cawahêrê w-tahārê mar rîksā. Wi-mzabnênay w-āwdinbay kazanc mahsûul kabîrā w-aygā b-zānên bețāa šafirāa w-kínizmāyāttā w-ǩādāmê w-swasāwātāa w-îkāāā wi-štāyā

\section{틀}

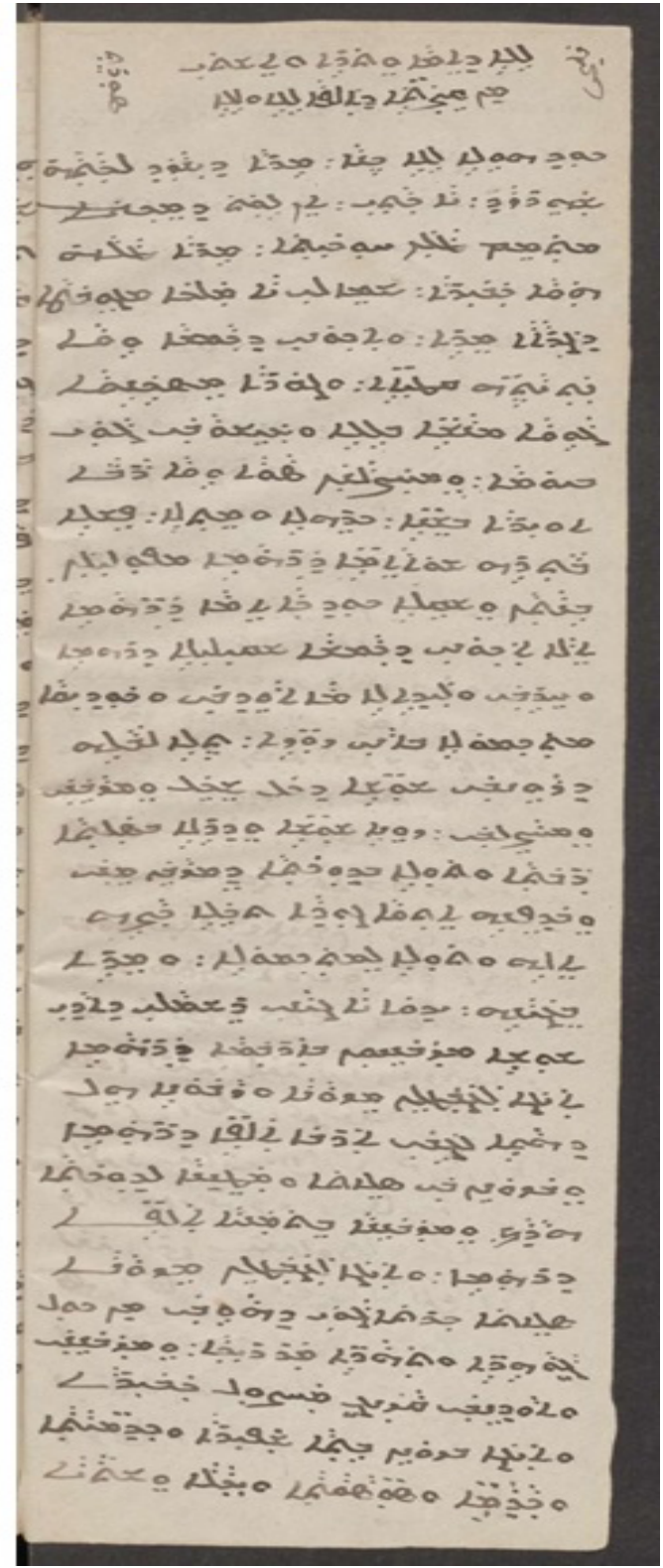


Wr. 30r

\section{ŠEBÊ ȘED U ŠÊST U DÛ
Ji Ç̂ROKA HEZAR ŠEB U ŠEBEK}

Hingî bû šebê ê dî: Got Dînazad li ǩsuškê Šehirzad: herê k̂ûška: heka tû nerazay

temam bika bo ma çîrok: Got bo wî qenca belê: Ez bihist ez k̂nûnkar nazdar di berber got: wi bray min ê pênca bû gûhe wî birînî: wi mirobê faqîira dikazit ji meroban bi šabê u bê diborit bi rojî. U babê me pîr bû u mazin zor çûna bi șalan: neǩoş bû u mir. U ma pašì heft șed deram beynama teqsîm kirin: $u$ her yekî sitend șed deram: meger biray min ê pençî stend daramê kूo u pê fekirî u nezanit çî pê biket: u bêgaboê di fekirît bi wan diraw. Heta li bîra wî di pê bikerît šûšan ji hemî terzan u bifrošit pê da qezanc biket: šûša kirî dana bi sebetek mezin u rûništ da bifrošit ji wan wi bi teništawî dîwar hebû pištî balga li wî u rûništ di fekîrît. Wi dibêjit bokno. Bizana ganê min. Ser malê min ê wan şûşan da bifrošim bi çar șed derama bêgaboê namînim ji kirîn wi-firotîn heta di bit nikmin çar hezar deram u pê da bikerîm sil'at u bikem li çiyak (cîyek) kî weșa da bifrošim bi hešt hezar deram. U bêgabê namînim ji kîrîn sil'atê êdî pêra di têda ji hamî terzan cewahira u tištan bibînî knoš: u bifrošim u têda qezenc u mehsûla gelek zor bikem u bêgabê knan bikirim baš u kadaman u k kadiman u hespan u biǩwam u bigêšim.

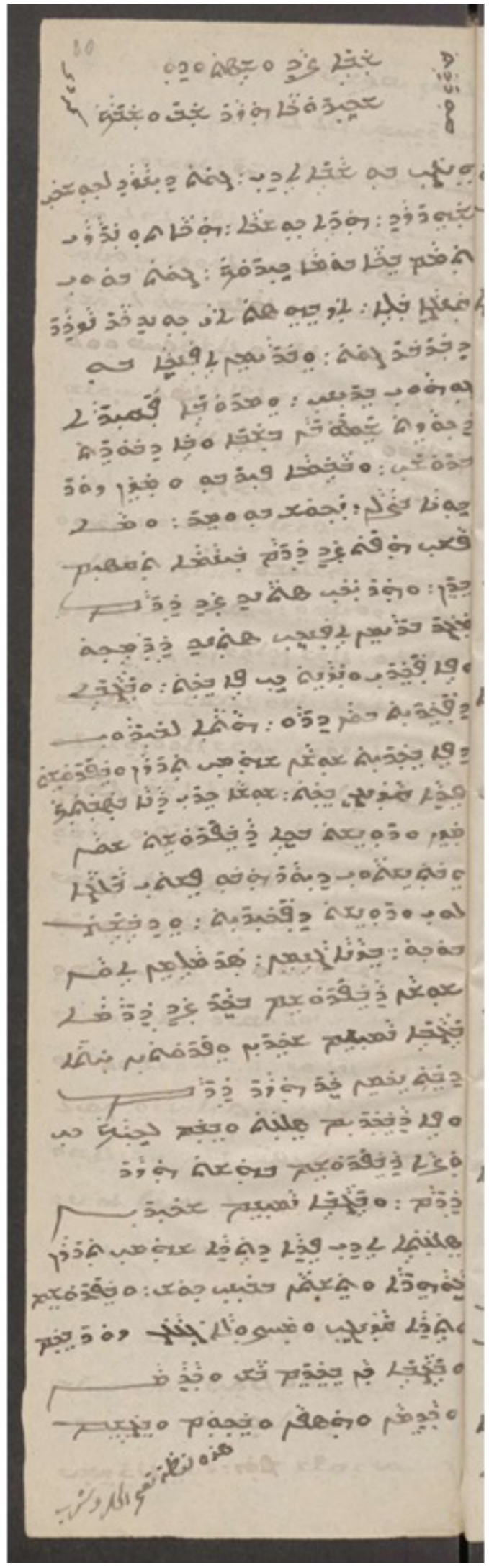


Wr. 30v

\section{Fellîhị̂}

B-daǩlin w-šătin w-gorin w-lakšoqin zamārā w-lā zamārtā bêmdîtā ilā b-mahidrinûn 1-gêbîi. Wê-bododin rašmālî in Alāhā 'āyin imā alfề dirhamê. Ādî

Kulêh bikيšāwā wêwā biǩcušāwêh w-salêkțāā d-šušê qāmêh b-imā dirhamê. Aygā āwu mhusiblê w-mere. Kûd pāyiš mindîyî imāa alfā darhamê. bațrdêk bid mšadrin dalālyātāā 1-țalābeutāa wi-bِtalbein b-nātāa d-malke w- wazirê. W-bifrišutāa wazîrān. Bid šimelî li-brāteh āhî kmiltêlā b-knāṣlātāāh w-šufrāh rešāyā w-randê b-mar kišyātāh. Wi-mcāhzênā alfā dênārê. In d-șêlûn b-dêlā. W-inlā b-šamlinā bi-ḅramtā d-fokā d-ḅābāh w-aygā dêhwêlā b-ḅêti b-zonen isrā ǩādāmê zorê aygā b-zonin 1-wištā d-malkê w-sargā mdêhwā mțu'ā b-marganyātāā mar țimā. W-aygā bid mar kwin kwālāwātāa bar knāșî w-qāmî wi-myamnî w-căfí. W-kud k̄āzêlî b-qāyêm qāmi we-ḅmāwtûlî b-šopeh wi-ḅātû āwu iltik. Ked ānā k̂êtnêh îwin. Wi-ḅšaqlin trê gûlamwāyyā w-matêninûn trê kyasê gāway alfā dênārê 1-naqdîyê. W-bid mbağḅšin alfā dinārê kinê tad yadî rabûtāā d-gyāni w-zorûtāa d-dunyê b-ênî bêgā bāâên 1-manzālî. W-in ătê kxā min mêl d-baḱtî b-yawenê wi-mbağbš̌inê kllātā. W-agr mātêlî̀ d-yarî b-madêdinā ilêh. Ham b-faqdênun

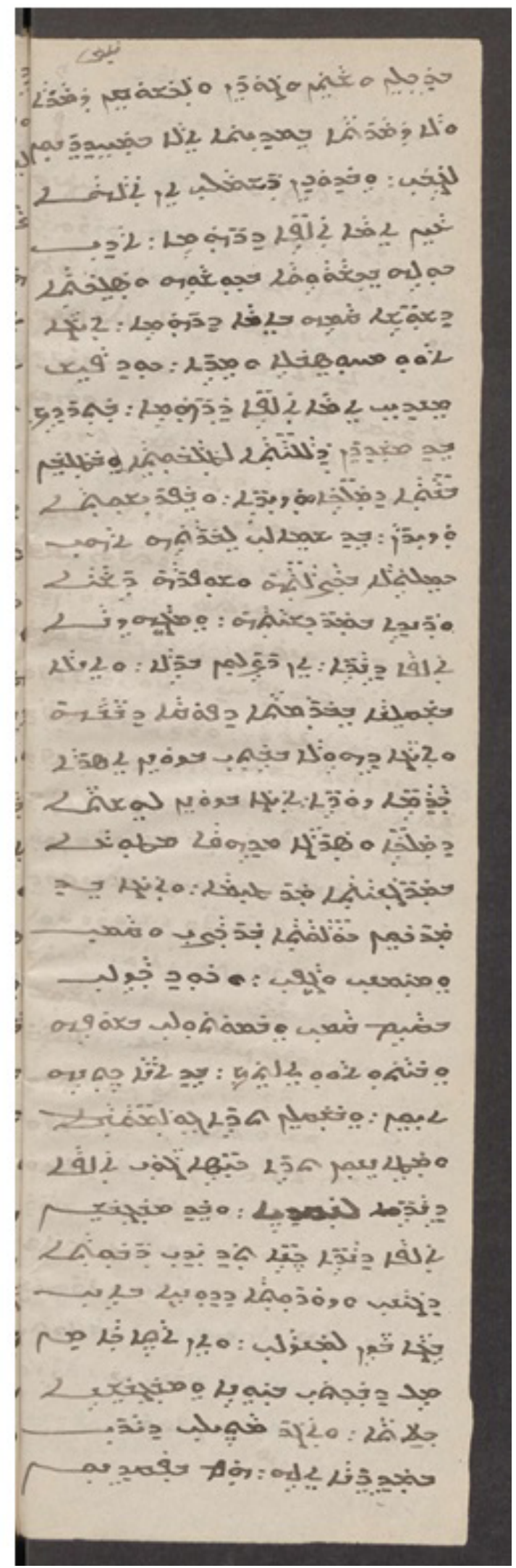


Wr. 31r

Di bikwam u markem u nehêlim sitarina u na sitarinê bi bajêrê meger da hazir bikem li nikmin. Dê çêkam ser mayay knom inšaelah șed hezar deram abo

hemî di fekirît b-dilawî. Û sebeta

ê šûšan li ber bi șed deram. Bệgabêê

aw hisibkir u got. Kengi bû

tišta min șed hezar deram. Pašî

denêrêm dalala li hwwaztena da bikwazim

kiçan šahan wa (û) wezîran. Dûmayî

wezîrama. Jê bihistim kiça wî ewî

kamila bi 'adetî u knoškoka baša

qenca bi hamê rengan. Û dê bidamê

hezar zêr. Heka qebûl kir çêbû̀: hekana

bistînim bi k̂̂rtî tifla babê wî

kengî bû li malê min. Dê bikirim deh

knadama biçûk. Bêgabêe di bikirim liḅsa

êd di šahan u zînek ji zîb bi cawahira

qîmetî gelek bî zor. û bêecarê

siwar bikem gûlama li ber pišta min u ber min wêji rastî u cepê. U hingî bibînî min

der bit ber min u di rûnišim bi šona wî

$\mathrm{u}$ aw di ronit ji nišîb. Jê zawayê wîma

u dê bistînim dû gûlaman

dê berkem dû kîsa têda hezar

zêr mehrawî. U dêbirim keleta

hezar zêr îdî da bizanit mezina

ganê min u biçûka dûnya bi çawê min

bê neqlê dê bêkêm li mala kno. U heka êk bêtji

țarafê jinamin dê bêramê pêškêša

u keleta: u heka bînit bo min yar yak

dê begegêrêm lêh. Ferman bikem

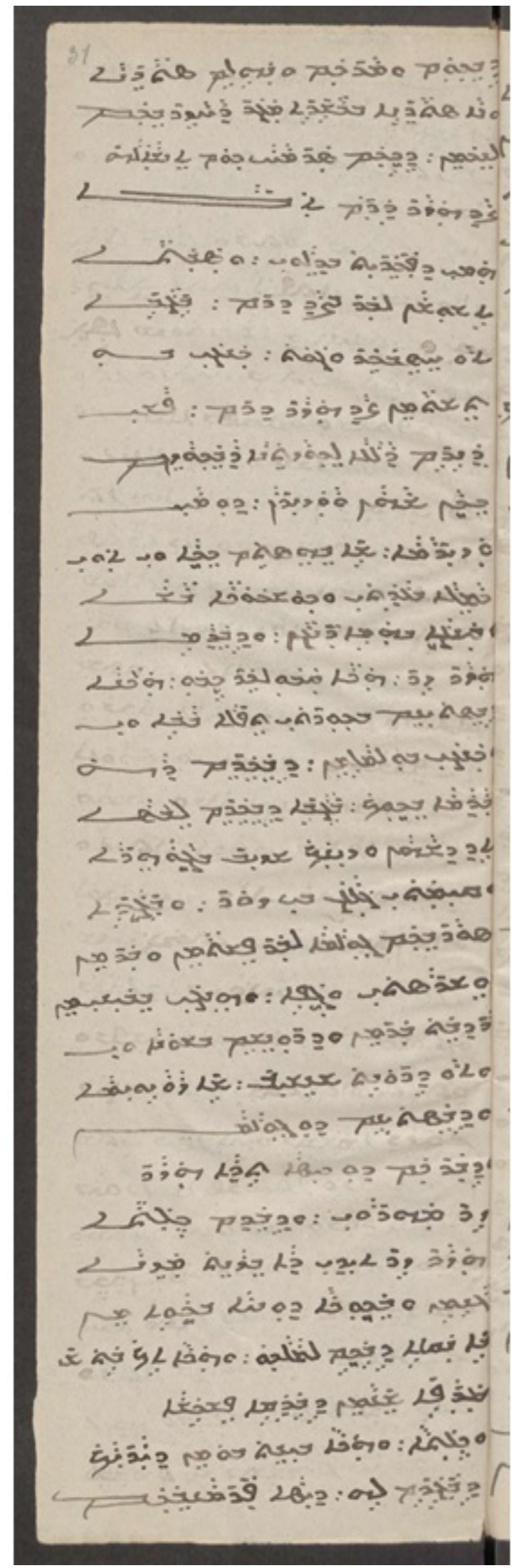


Wr. 31v

\section{Suret}

b-hawutāa d-hāalî kud îliflûn

iwêdlûn hādākn. B-faqdênûn de-mcāhzîlā w-hawûtā d-betîi w-kud ātyā

'idānā d-tanāyutāa êmbaǩtî 1-wêšlî

Cûwlê rêšāyê wi-byatqin b-duktāa ilêl

d-dịbāc b-tākin lakfațlin yamnê w-lā cafe mzāwdānûtāa d-šenāyûtîn w-yaqîrûțā we-ḅtāwnā baḳtî klîțā kssahrā kmîlā bsiqlāh wi-ḅšûfrāh w-ānā lakkêrênb̄ā mrabuûtā wi-pêtyuțā hil d-āmrî an d-hadrî̀ yā stādā dîyyān w-māran bakktûk kn kamtûk mol ilāh diklîtêlā 1-gêbuk iwod karām ilāh bikzzêtāa çûnki chêlā mêsmāk̄ā. Êgā b-marmin rêšì wi-bِkêrên ilāh kֵ kdā kyārtā wi-ḅmantịiā 1-zāwdāh. Wi-ḅqêmên ānā wi-mk̄ālfin qimašì wi-ḅlāwšin bišrandê minay w-intêlî gādi-trê b-kêlātā dê-trê lakkkêrên ilāh d-kālî qāmî w-țalbî minî gahātāa kabîrê b-kêrên ilāh b-gêbā d-ênî w-gākêrtā b-kêfin 1-ra'ā wi-ḅpêšin hādāk hil d-kxālsạa qlāwtāh aygā b-faqdin kikmā gulamwātāa tad mātîi kîsā gāwêh knmišmā dênārê b-yāwinê tā sarqyātāa wi-ḅpaqdênûn di-mwāhdịlî imāh. W-kûd mātîlā b-kêrên ilāh wi-bodamkên w-lakmaḥkin mināh d-āmrî ilî dêgyānêh rabtêlā b-datnāa imāh b-'ašqā îdî w-biçç-amrā yā stādî ǩcor 1-ḳ̂êdamtûk kimšahyā qrotûk

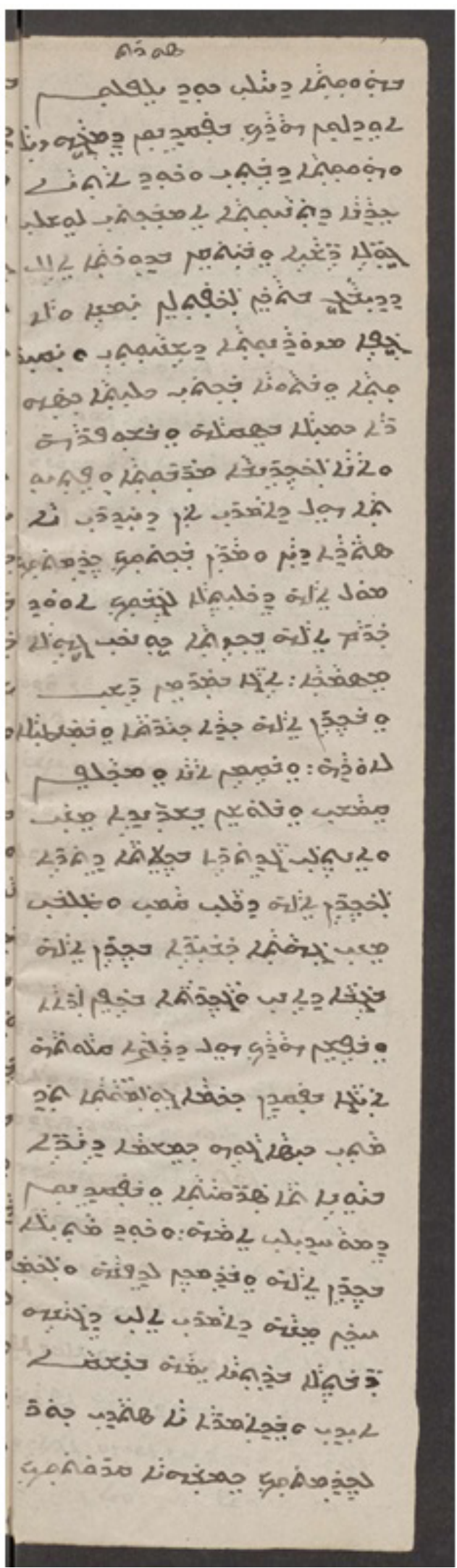


Wr. 32r

\section{Qurdat}

Bi dalalî halê min kengî fề bûn u kirin çêkin weșa bİ fermim li wan da hizrkan u nazê malêmin. Çi gab hatawa bi waqtê tenhayî ligal jina min li berko ce'bêe êbaš u dê rûnim bi çî bilind li díbaca pal dêdem berê kno nadem li destî ya li cabê ji mezinatî min u meqûlatî wi ger niya. Jê jina min di bit rawesta wek bedrî bi libas u zînet wî u camalî $\mathrm{u}$ ez berê kno nedamê ji 'azamet u mequlatî heta dê bêjin wan kî hazir bin. Ey knûda wandê ma u agay ma jinê ta karamê ta berê kno bidê wê wesța li nik ta bika kerem li wî bi dîtin ji ber zehmetî ji wesțanê. B.ê carê serê kno helawestim u di bînim carak bi yek dîtim u dê ben li odê. Dirabim ez u tebdil dikem qûmašê min u ber kno biken menctir ji wan u heka hatin car dî bi kêleta dû wan nabînim ji wî li bermin wesțan ji min k̂́wazin gelek caran da li wî bifikrim weha bimînim heta cilwawî temam bit bêcarê bi fermim li hind gûlama. Da bînin kîsek tê da penc șed zêr dê bidem bo kêbanyan wi liwan emir dêkem da tenha biken min li gelî. U hingî hina u bị̂înim u dêrazim bi teništî u nakêebim li gelî da bêjin bomin giyanê wî mezina. Dayka wî têd u mecd ketmin destmin wi dibêjit herê agêmin binêr li knarama kno di bêt da nizîk bîli wê

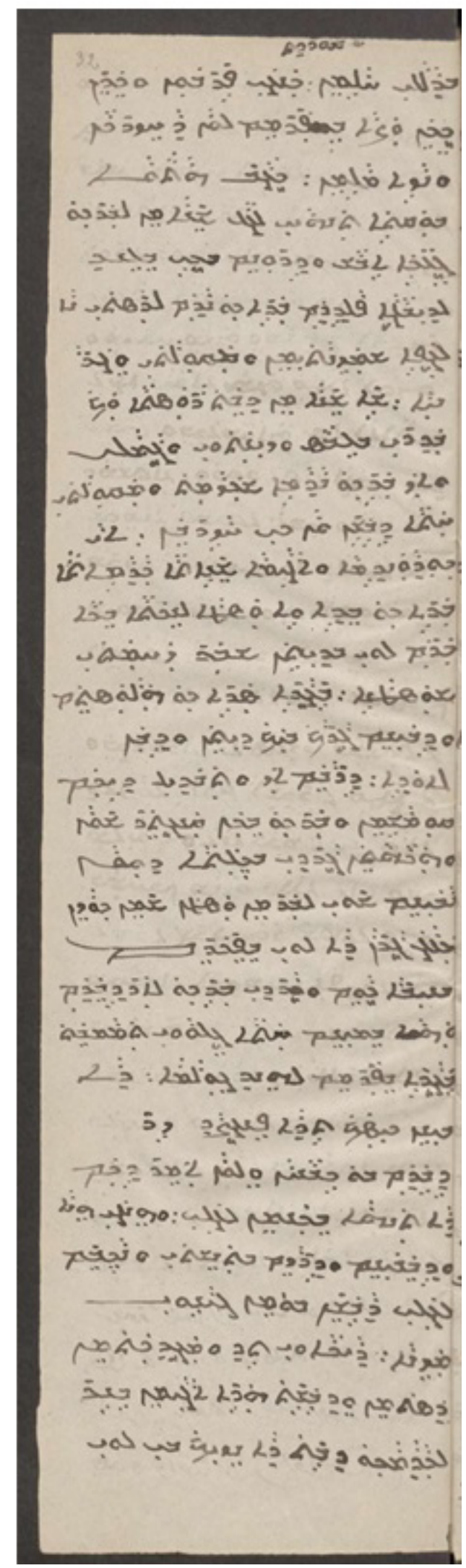


Wr. 32v

Mbasim lịbāh. Lakmadîrin ilāh ciwāb kûd kૂāayāā ādî minî b-qêmā b-našqā aqlî gahățā w-bid-amrā yā stārî. Brātî zortêlā w-laǩzêlā gawrā kûd kāāzyā minûk ādî darq(û)ûlûtā ktāwir libāăh mol ilāh w-mahkî mināh wi-mb̄āsim li-bāāh aygā b-yāwālā imāh qatgāa gāwêh kāmrā w-bid amrālāh îmê 1-zagitā w-maštêlê. W-kûd ātyā 1-gêbî bid šāwqinā smiǩtā qāmî w-ānā tikyā mrabuutāā d-gyānî hil d-āmrā ānā myûqrā b-gānî w-'aziztā wê-bššāwqinā smik̄tā qāmî d-țamā țimā d-rûnûtā w-yadtā d-ānā šulțānêwin w-biid-amrālî yā stādî b-kênûtāā d-alāhā ilûk lāmadêrêt qatğā m-îdî w-ānā ḱ kdamtûk w-lā kšaḥkin mināh b-lêcā ilî w-bid āmrā garg har šatitê w- bid maqirwālê 1-kûmî b-nafșin îdî b-ṣalmāh wi-ḅrapsināh b-aqlî w-ḅid-āwdin hādāḳ. Aygā ripișlê b-aqlêh w-qihlāa b-salikțā d- šûsê. Wêwā b-dûktāa 'ilîtāa min artā kwišlê ilid ar'ā w-pišlê twîikā kûlmā d-î́bê

Tercemtu hada li-ecli katịirike lakin hiye hikayetun baridetun fahiyetun bila milhen qețtu bi'1-'arabî bi-lugeti'1-Muṣul yequlune hadihi we emtaliha (lewas)

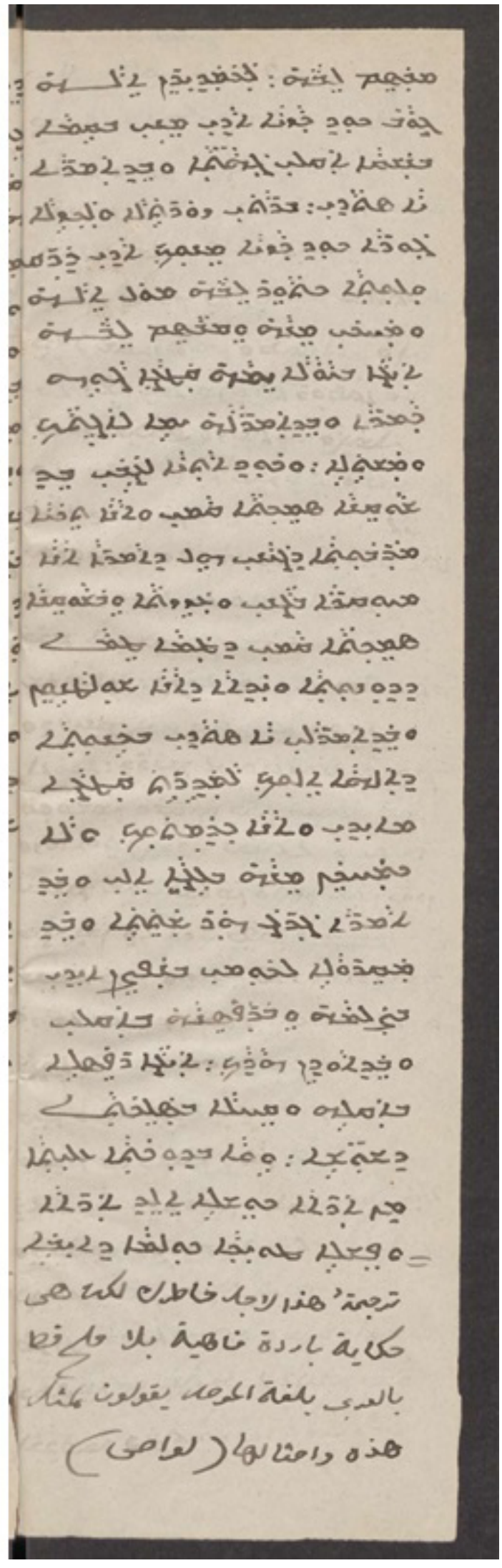


Wr. 33r

Dilê wî knoš bika: benagêrêm bo wî cewabek hingî dê bînit weșa ji imin dê rabit maç di ket piyê min caran u jê dibêjit herê ag̉ay min. Kiça min biçûka u nedît mêr çî gab di bînit ji te eb 'aksa wî dilê wî šikest dê bit berê kno bidêy u b-ekêba li gel wdilê wî kૂoš bika bekibiba li gel $\mathrm{u}$ dilê wî fincanê tê da mêh wi di bêjitê sor kiwo li agay ta u bidê da biknwat: $u$ hingî dê bêt nik min jê nehêlim wasta li ber min u ez paldam ne 'azamet ê kxû ta da bêjêt ez delalim biganê kno $u$ meqûl $u$ jê u jê dihêlêm westa li ber min da bizanit țama ê rezîlan u bizanit di ez k̂ûndkarim u dê bêjet $\min$ Ey Agê min bi haqîi ǩnûdê li ta nebegêra fincanê ji destî min u ez kedama tema u nakêebêm li gel di lezît li min u bêe ecr di bêjêt helbet dê bikwway u jê nêzîk di ket li debô min. Destê kọo lêd dem bi șûreta wî u pilêdem bi pêh u dê bikem weha. Bêgabê pilêda bi pey wî u keta bi salek ê šušan bi çêh hawras bûn ji 'ardê hat nišin li 'ardê u gišt šikesta hemî di têda bû Kțûlî odî hûkîto b-qurdat Mturcmolî min 'arabî. ilodok Omrin b-doyêlo w-lakțoyowo d-howno Mtûrcomto ilo to kotir dê-lyofo Lûšono d-qurdoyê d-yalî dûn b-nošê

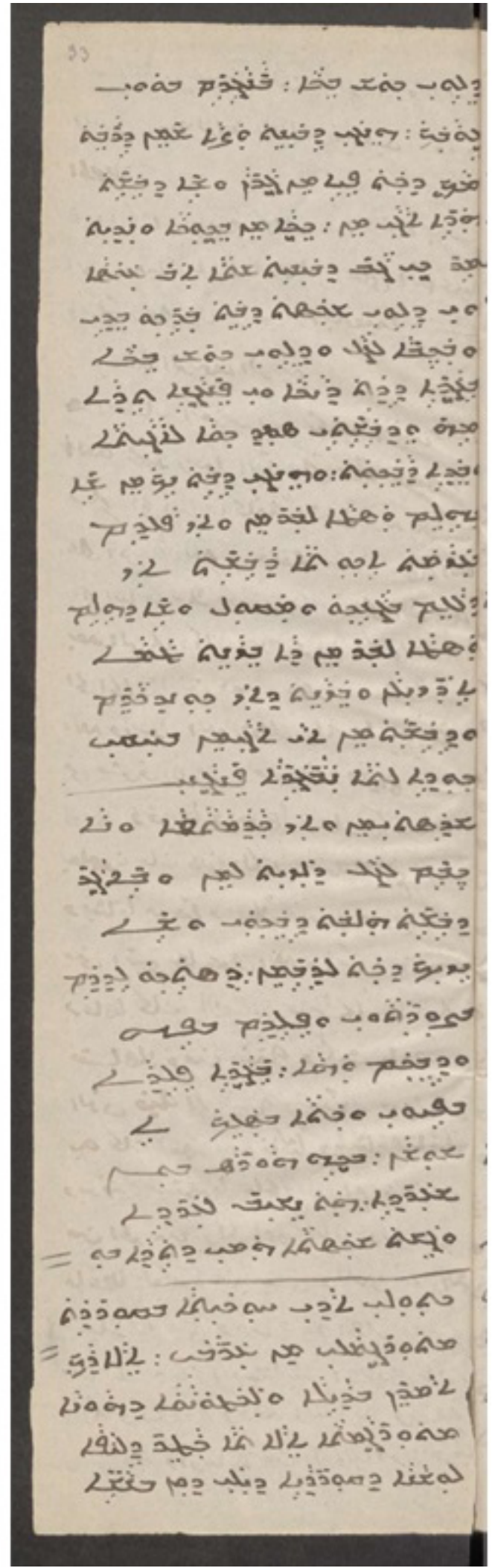




\section{BERAWIRDKIRINA WERGERÊN ÇîROKÊN HEZAR Û YEK ŞEVÊ DIGEL WERGERA JEREMIAS SCHAMIR}

Em ê di bin vî sernavî de wergera Jeremias Schamir a ku ji bo Kurdî kiriye, bi du awayan berawird bikin. Em ê pêşî vê wergerê bi wergerên bal zimanên din ên weku Erebî, Farisî, Kurdî (Soranî) û Tirkî re berawird bikin. Paşê em ê wergera Schamir a bo Kurdî bi metna resen re berawird bikin ku ew ji ber hatiye wergerandin (Erebîya çîrokê ya di berhema Faris el-Shidiac de). Herwiha em ê digel vê muqayeseya wergera Kurdî û Fellîhî jî bikin.

Dema em bala xwe didin vê çîrokê, di çapa Erebî de (Al-Muqaffa, 1935, 101-102) ji nav şeva sî û yekan de dest pê dike û di dawîya şeva sî û duyan de diqede. Di çapa Farisî de (Tesûcî Tebrîzî, 1389/2011, 136142) di nav şeva sî û yekem de bi sernavê "Hîkayetî Bîgûş̧ (Hîkayeta Bêguh)" dest pê dike û di dawîya şeva sî û duyem de diqede. Di çapa Tirkî de (Onaran, 1992, 146-165) jî çîrok bi sernavê "Berberin Beşinci Kardeşi el-Aşar'ın Öyküsü (Hîkayeta el-Aşarê Birayê Pêncemîn ê Sertiraş)" weku çapa Erebî û Farisî di nav heman şevan de dest pê dike û bi encam dibe. Lê di ya Erebî, Farisî û Tirkî de cihê qutbûna çîrokê ya şeva sî û yekem û sî duyem hem ji ya Soranî hem ji ya resen (wergera Schamir) cudatir e. Çimkî di çapa Soranî de (Daraxa, 2015, 207-214) çîrok di nav şeva sî û duyem de bi sernavê "Birayê Pêncemî Sertaşî Zorbillê" dest pê dike û di dawîya şeva sî û sêyem de diqede. Herwiha di çapa Soranî de qutbûna çîrokê ya di navbera her du şevan de weku ya resen e. Yanî ya Soranî û ya resen di heman derê de qut dibin û derbasî şeva li dû xwe dibin. Ferqeke eşkera ya din a di navbera çîroka resen û çapên din de şevên çîrokê ye. Di çîroka resen de bi sernavê "Şebê Şêst û Dû-Ji Çîroka Hezar Şeb û Şebek" çîrok dest pê kiriye û bêyî ku temam be yan jî derbasî şeva sed û şêst û sêyem be, qut bûye. ${ }^{9}$ Lê di çapên din de çîrok bi piranî ji şeva sî û yekem dest pê dike û di şeva sî duyem de diqede û tenê di çapa Soranî de ji şeva sî û duyem dest pê kiriye û di şeva sî û sêyem de qedîyaye. Mimkûn e ev ferq ji ber metnên esil in ku ji ber wan hatine wergerandin. Bi îhtîmaleke mezin wisa dîyar e; metna Faris el-Shidiac ku Jeremias Schamir ji ber wê wergerandiye, ji çavkanîyeke cuda hatiye wergirtin.

Çîroka resen jî û hemû çapên din jî bi heman awayî dest pê dikin, her çiqas vegêran sedî sed ne weku hev bin jî naverok weku hev in. Herwiha parîkirina mîrasê, qîmeta mîrasê û paşê şêwaza karkirinê bi wê mîrasê ya birayê pêncem (el-Aşar) û herwiha derbasbûna monologa di nav xeyala xwe de di hemû çîrokan de weku hev in. Tenê carinan hin teswîr ji hev cuda ne yan jî kurtbûn û dirêjbûna teswîran ji hev cuda dibin. Mesela pasaja ku birayê pêncem xeyal dike dê çawa zengîn be û pere û sermayeya wî li hev qat be, di çîroka resen de dirêjtir hatiye vegêran. Di nav çapên din de ya herî nêzîkî çîroka resen çapa Soranî ye. Ji bilî şêwaza vegêranê û kurtbûn û dirêjbûna teswîran zîncîreya rûdana çîrokê di hemû varyantan de weku hev in.

Werger heya nîveka duyem a sedsala 20an nebûbû dîsîplîneke serbixwe, her çiqas pratîka wergerê hebe jî li ser çawanîya wê nîqaş gelek nehatibû kirin. Loma berî nîveka duyem a sedsala 20an bi piranî werger bi awayekî rasterast/yekser ango peyv bi peyv (word for word) an jî serbest ango mane bi mane (sense for sense) dihat kirin (Yıldrımçakar, 2016, 8). Lê ya balkêş ew e ku li gorî Jeremy Munday berî nîveka duyem a sedsala 20an werger bêtir di kursan de ji bo fêrkirina ziman bi rêbaza wergera ziman (language translation method) dihat kirin (Munday, 2010, 419-428; vgz. Yıldırmçakar, 2016, 19) ku ev rêbaz nêzî rêbaza wergera peyv bi peyv e. Çimkî dema em bala xwe didin wergera çîroka Şebê Şêst $\hat{u} D u$ ya ku Jeremias Schamir ji kitêba Faris el-Shidiac wergerandiye, gotina Munday piştrast dibe. Çimkî kitêba el-Shidiac ji bo fêrkirina Erebî bi navê A Practical Grammar of The Arabic Language With Interlineal Reading Lessons, Dialogues And Vocabulary (Pratîkeke Rêzimana Zimanê Erebî digel Rahênanên Xwendin, Dîyalog û Peyvan) hatibû amadekirin. Çîroka Şeb Şêst $\hat{u} D u$ jî bi awayekî nîvco ji bo fêrkirin û muqayesekirina zimanê Erebî û Îngilizî di kitêbê de hatibû danîn (el-Shidiac, 1856, 52-62). Tê dîtin ku el-Shidiac çîrok peyv bi peyv wergerandiye Îngilizî û dema em bala xwe didin wergera Kurdî ya vê çîrokê ya ku Schamir wergerandî (1883, wr. 29v-33r), em heman mantiqê dibînin. Li vir li ser wergera Schamir çend nirxandinan dê bên kirin û dûre

9 Helbet ev qutbûn ne ji ber nebûna wergerê ye. Me berê jî gotibû, Jeremias Schamir, wergera vê çîrokê li ber kitêba Faris el-Shidiac kiriye ku di wê kitêbê de çîrok wiha nîvco ye ango tam nehatiye neqilkirin. Ev yek jî bi îhtîmaleke mezin ji ber çarçoveya kitêba el-Shidiac e ku ev kitêb, kitêbek e fêrkar a rêzimana Erebî ye û ev çîrok jî ji bo temrîna ziman li wir hatiye neqilkirin. Loma el-Shidiac lazimî nekiriye ku temamê çîrokê bide û wiha nîvco hiştiye. 
encam bê pêşkêşkirin.

Wisa xuyaye Schamir, bi piranî li gorî wergera peyv bi peyv tevgeriyaye. Ji bo vê yekê em dikarin çend mînakan li vir nîşan bidin. Mesela di wereqa 30r de di rêza yekem û duyem a çîrokê de ji Erebî: " "قاَلت دينازاد لأِختها شهرزاد....” bo Kurdî: “Got Dînazad li xuşkê Şehirzad” bêyî ku midaxeleyeke sentaksî (Dînazadê ji xuşka xwe Şehirzadê re got) bê kirin hatiye wergerandin. Yanî di Erebî de rêza peyvan çawa bûye, di Kurdî de jî heman rêz hatiye şopandin. Bi vî rengî çend mînakên din jî wiha ne:

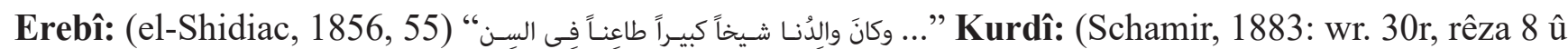
9em) "û babê me pîr bû û mazin zor çûye bi salan..." Kurdîya îroj: "û babê me pîr û mazin bû, di salan zor çûye."

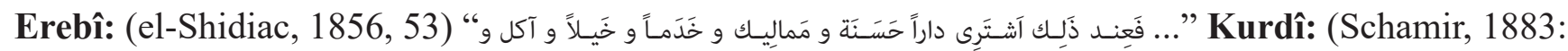
wr. 30r, rêza 30 û $31 \mathrm{em}$ ) "û vê gavê xan bikirim baş û xadama û xadiman û hespan û bixwem û..." Kurdîya îroj: "û vê gavê xanîyekî baş, xidama û xadiman û hespan û xwarinan bikirim û..."

Ji bilî wergera peyv bi peyv em carinan dibînin ku Jeremias hin peyv û qaliban jî şaş nivîsîne. Bi îhtîmalek ev nîşaneya başnezanîna zimanê Kurdî ya Jeremias e. Mesela di wereqa $31 \mathrm{r}$ de di şûna xwarinê û vexwarinê de jî peyva xwarinê gotiye. Jeremias dibêje min Kurmancîya aliyê Hekarîyê (Behdînanê) tercîh kiriye ku ew ya herî fesîh e (1883, wr. 29r). Lê tişta tê zanîn di devoka Behdînanê de xwarin û vexwarin ji yek cuda ne. Ji bilî vê mînakê dîsa di wereqa 31r de Jeremias ji bo stranbêjê mêr û stranbêja jin ango dengbêjên mêr û jin peyvên maqûl hilnebijartine û heta di wî qismî de mirov wergera wê fam nake: "û nahêlim sitarina û na sitarinê bi bajêrê..." Berevajî ku di Erebî de bi awayekî fesîh hatiye gotin (el-Shidiac, 1856,

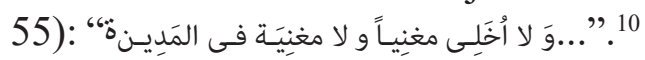

Helbet hin alîyên serincrakêş jî hene di nav wergera Jeremias de. Mesela li hin deran ji wergera peyv bi peyv bêtir xwe bi aliyê wergera maneya peyvê de biriye. Mesela di Erebî de (el-Shidiac, 1856, 53) "قالَت لَها

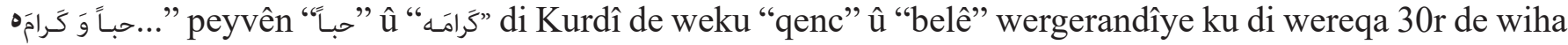
hatiye wergerandin: "Got bo wê qenc e belê..."

10 Mirov tê digehe ku Jeremias mê û nêrtiya Kurdî weku ya Erebî nirxandiye û loma di vir de ketiye wê xeletiyê û li gorî xwe du bêje afirandine. 


\section{ENCAM}

Werger ji bo zimanan şibakeyeke nû û nefeseke taze ye. Çawa ku mirov di peywendîyê de ne, divê ziman jî di peywendîyê de bin da ku her biçe nûvejen û zengîn bibin. Bêguman rêyeke herî maqûl ji bo vê peywendîyê jî werger e. Loma li gorî vê nêrînê di sedsala 19an de ku werger hêj ew qas ne di rewacê de bû bi taybetî ji bo zimanê Kurdî, ev xebata Eduard Sachau û Jeremias Schamir di serî de xebateke zor giring e bi hebûna xwe. Çimkî ji gelek alîyan ve çi zimannasî, wergernasî çi jî dîrokî be ev xebat dikare bo me gelek mifadar be îroroj.

Di encama xebata me de xuya bû ku ne tenê çîroka Şebê Şêst û Dû-Ji Çîroka Hezar Şeb û Şebek herwiha kitêba Faris el-Shidiac a bi navê A Practical Grammar Of The Arabic Language With Interlineal Reading Lessons, Dialogues And Vocabulary li ser pêşnîyaza Sachau hema hema bi giştî ji hêla Schamir ve hatiye wergerandin ku beşa yekem a destxeta Sachau 200 û destxeta bi navê Sachau 250 nîşaneya vê yekê ne. Helbet berî vê xebatê, hin xebatên rêzimanî yên weku xebata Maurizio Garzoni ya bi navê Grammatica e Vocabolario Della Lingua Kurda (1787) derketibûn. Lê ev xebat belkî ji hêla ku werger e, xisûsîyeteke xwe ya taybet heye.

Xisûsîyeteke din a wergera Jeremias jî ew e ku herî kêm bi du zimanan an jî bi sê zimanan e. Bo nimûne çîroka ku mijara xebata me bû, ji zimanê Erebî hem ji bo zimanê Fellîhî hem ji bo zimanê Kurdî hatiye wergerandin. Ev jî ji hêla berawirdkirina van her sê zimanan ve avantajekê dide lêkolîneran. Bi taybetî berawirdkirina zimanê Kurdî û Siryanî (Fellîhî) ku werger zor kêm in di vî warî de.

Encameke din jî ew e ku zimanê Kurdî di sedsala 19an de li mintiqeya Rojhilata Navîn, zimanekî bazarê bûye û tesîr li şênîyên devdorê xwe jî kiriye û ketiye bala gelek lêkolînerên bîyanî. Vê rewşê kiriye ku hin werger bo zimanê Kurdî bên kirin di wê serdemê de.

Axirî di bareyê wergera Jeremias Schamir de jî divê bê gotin ku ne wergereke pir serkeftî bûye. Her çiqas li gorî wê serdemê rêbaza wergerê ya berbelav a peyv bi peyv be jî vê rêbazê kiriye ku kêmek metna armanc (Kurdî) neyê têgehiştin. Herwiha hakimnebûna tam a Schamir li zimanê Kurdî jî kiriye ku werger kêmek jî lawaz bibe. Herwiha li gorî ku Schamir bixwe gotiye; ew di wergera Kurmancî de zêde ji dil nebûye û nexwestiye bike, lê wî ji bo xatirê Eduard Sachau ew çê kiriye. Herwiha dîsa wî aciziya xwe ya ji rewşa zimanê Kurdî dîyar kiriye ku li gorî wî ew zimanekî bê qayîde û bê teşe ye. Dema em van faktoran hemû li sîqala aqilî bidin dê zelaltir be ku çima wergera Schamir ji hin aliyan ve lawaz bûye. 


\section{ÇAVKANî}

Avc1, Remzi. Seyahat Notları ve Oryantalist Bilgi Üretimi: Eduard Sachau (1845-1930) Örneği. Diyalog Interkulturelle Zeitschrift Für Germanistik, 8/1, (2020), 29-47.

Azîzan, Herekol. Lavijên Mîr Miheme. Firat Cewerî (amd.). Hawar, Hej. 29, (1941), 727-729.

Bedirxan, Celadet Alî. Lavij. Firat Cewerî (amd.). Hawar, Hej. 25, (1934), 654-662.

Bulut, Aziz. Türkçe-Süryanice/Süryanice-Türkçe Sözlük. Hengelo Hollanda: Süryani Mor Efrem, 1996.

Daraxa, Cewher Mehmûd. Hezar û Yek Şewe. Berg (1.), Çapa (4.). Silêmanî: Endêşe, 2015.

Dehqan, Mustafa and Mengozzi, Alessandro. A Kurdish Garshuni Poem By David Barazne (19th Century). Hugoye: Journal of Syriac Studies, Vol. 17.1, (2014), 53-79.

Digitale Bibliothek der SBB https://digital.staatsbibliothek-berlin.de/ (24.02.2021).

Dinno Khalid. The Deir Al-Za'faran and Mardin Garshuni Archives, Hugoye: Journal of Syriac Studies, Vol. 17.2, (2014), 195-213.

Direkçi, Lokman. Kürtçe Gerşuni Bazı Metinler ve Alfabeleri. Mardin: Mardin Artuklu Üniversitesi Yaşayan Diller Enstitüsü Süryani Dili ve Kültürü Anabilim Dalı, Yayınlanmamış Tezli Yüksek Lisans Semineri, 2018.

Dûşî, W. el-Lawîc; Teratîl Enşedha el-Mifriyan Mar Basîliyos Şemû'n el-Sanî, el-Heseke, 1996.

Ebied, Rifaat and Al-Jeloo, Nicholas. Some Further Letters in Syriac, Neo-Aramaic and Arabic Addressed to Eduard Sachau by Jeremiah Shāmīr. Journal of Assyrian Academic Studies, 24/1, (2010), 1-45.

Ergin, Ramazan. Süryani Dilsel İşaretlerle Yazılmış Kürtçe İlahiler (Lawîj-Gerşuni) Kürt Mesihiler ya da Midyatlı Kürtçe Konuşan Mesihiler; Süryani Dilsel İşaretli Kürtçe İki İlahinin Teolojik ve Dilbilimsel İçeriği. Uluslararası Midyat Sempozyumu, (7-9 Ekim 2011), 417-445, Mardin: Mardin Artuklu Universitesi, 2011.

Garzoni, Maurizio. Grammatica e Vocabolario Della Lingua Kurda. Roma: Sacra Congregazione di Propaganda Fide, 1787.

Gemi, Ahmet. Turks in The Thousand and One Nights, Turkey, Looking Behind and Before, London: Published by AGP Research, 2016.

Gottheil, Richard. Achmed Taimur Pasha, Thedor Nöldeke, and Edouard Sachau: An Appreciation. Journal of the American Oriental Society, Vol. 51, No. 2, (1931), 104-107.

Harrak, Amir. Syriac and Garshuni Inscriptions of Iraq (Répertoire des Inscriptions Syriaques 2) Académie des Inscriptions et Belles-Lettres, 2 vol., I. Texte \& II. P1., Paris, 2010.

İshtarTv. Telkef, https://www.ishtartv.com/en/viewarticle,35680.html (18.02.2021)

Kiraz, George Anton. Tūrāṣ Mamllā: A Grammar of the Syriac Language, Volume 1/Ortography, Piscataway, New Jersey: Gorgias Press, 2012.

Kiraz, George Anton. "Garshunography: Terminology and Some Formal Properties of Writing One Language in the Script of Another”. Scripts Beyond Borders: A Survey of Allographic Traditions in the Euro-Mediterranean World, Johannes den Heijer et al. (ed.). 65-75, Leuven: Peeters, 2014.

Munday, Jeremy. "Translation Studies". Handbook of Translation Studies, Gambier Y. and Doorslaer L. (Ed.). Vol. 1, 419-428, Amsterdam: John Benjamins Publishing, 2010.

Murad, Yahya. “E. Sachau 1845-1930”. Mucemû'l Îsmaîl-Musteşriqîn, 422-423, Beyrût, 2004.

al-Muqaffa. Elf Leyle we Leyle. Misır: Bulaq al-Amiriya Press, 1935.

Nicholson, Reynold. A. A Literary History of the Arabs. New York: Charles Scribner's Sons, 1907.

Nicholson, Reynold. A. Binbir Gece Masalları, Süleyman Tülücü (Çev.). Atatürk Üniversitesi İlâhiyat Fakültesi Dergisi, Sayı: 27, (2007), 307-313.

Onaran, Alim Şerif. Binbir Gece Masalları. Cilt (2.), İstanbul: Afa Yayınları, 1992.

Özaydın, Abdülkerim. “İbnü’l-İbrî”. Türkiye Diyanet Vakfi İslâm Ansiklopedisi, 21/92-94, Ankara: TDV Yayınları, 2000.

Rudenko, Margarita Borisovna. Danasîna Koleksîyona Destxetên Kurdî yên li Lenîngradê. Moskova: Çapxaneya Edebiyata Rojava, (1961). (niv.) (Orî̀înala pirtûka Rodenko: Руде́ нко Маргари́ та Бори́ совна, Описание курдских рукописей ленинградских собраний, Издательство Восточной Литературы, Моckba, 1961.)

Schamir, Jeremias. (1883) Sachau 200, https://digital.staatsbibliothek-berlin.de/werkansicht?PPN=PPN871612011\&PHYSID=PHYS_0025 (24.02.2021).

Schamir, Jeremias. (1882) Sachau 250, https://digital.staatsbibliothek-berlin.de/werkansicht?PPN=PPN813661021\&PHYSID=PHYS_0005 (26.02.2021).

Sehab, Ebu'l-Qasim. “Sachau Edward”. Ferhengê Xawerşinasan; Şerhê Hal ve Xidmatê Danişmendanê Îranşinas ve Musteşriqîn, 308, Tehran: Danişgahê Tehran, 1356/1987.

el-Shidiac, Faris. A Practical Grammar Of The Arabic Language With Interlineal Reading Lessons, Dialogues And Vocabulary. London: Bernard Quaritch, 1856. 
Tammu, George. "Ricalu’n Necbethum Kermelîs: Cebraîl bin el-Qiss Îshaq el-Kermelîŝ̀”. ankava.com, (2012) https://ankawa.com/forum/ index.php?topic=609636.0 (22.02.2021)

Tesûcî Tebrîzî, Abdulletîf. Hezar û Yek Şeb, Tehran: Întişaratê Şehrzad, 1389/2011.

Weil, Gotthold. Festschrift Eduard Sachau Zum Siebzigsten Geburtstage. Berlin: Verlag Von Georg Reimer, 1915.

Yazıcı, Hüseyin. "Seyahatnâme”. Türkiye Diyanet Vakfi İslâm Ansiklopedisi, 37/9-11, Ankara: TDV Yayınları, 2009.

Yıldırımçakar, Ziyattin. Werger Wek Kirineke Çandî; li ser Rêyên ji Wergernasîyê ber bi Kurdolojîyê ve, Mardin: Mardin Artuklu Üniversitesi Türkiye’de Yaşayan Diller Enstitüsü Kürt Dili ve Kültürü Anabilim Dalı, Teza Çapnebûyî ya Masterê, 2016.

Ziriklî, Hayreddîn. "Karl Edward Sachau”. el-A 'lam, c. IV, 64, Beyrut, 1955. 


\section{PÊVEK: TRANSLITTERASYONA TÎPAN}

Siryanîyan bi sê xetên ji hev cuda nivîsîne. Ya ewil bi navê "Esțrangelo" tê nasîn ku ev xeta herî kevin û klasîk e ku Sîryanîyan bi kar anîye. Her çiqas îroroj zêde pê neyê nivîsandin jî di nivîsîna sernavên xebatên zanistî û hin metnên taybet de ev xet xuya dike. Ev xet bi navên "Serto", "Pşito" jî tên binavkirin û bi piranî di nivîsandina zaraveyê Siryanîya Rojava de tê bikaranîn. Xeteke din jî bi navê "Madnḥoyo" tê nasîn û di nivîsandina zaravayê Siryanîya Rojhilat de tê bikaranîn. Şêwazeke tîpan a di navbera xetên "Estrangelo" û "Serto" de ye. Ji bo ku di vê xetê de tîpên bideng bên nîşandan, li ser an di bin herfan de hin hereke tên danîn ku ev sîstemeke kevnare ya nivîsandinê ye. Destxeta di xebata me de bi "Madnhoyo" hatiye nivîsandin. Tenê ji bo hin dengên xerîb yên ku di Siryanîya Rojhilat de tunene, hin revîzasyon hatine kirin. Mesela ji bo dengê "ç", "c" û “j” hin sembolên nû hatine danîn.

\begin{tabular}{|c|c|c|c|c|}
\hline Transliterasyon & Xetê Erebî & $\begin{array}{c}\text { Xetê Kurdî } \\
\text { bi Tîpên Erebî }\end{array}$ & $\begin{array}{l}\text { Xetê Suryanî } \\
\text { (Mednhoyo) }\end{array}$ & $\begin{array}{l}\text { Xetê Surat } \\
\text { (Fellîhî) }\end{array}$ \\
\hline$" \mathrm{E} / \mathrm{e}$ & 1 & 1 & 2 & 2 \\
\hline $\mathrm{B} / \mathrm{b}$ & ب ب & ب ب & $=$ & $=$ \\
\hline$\underline{B}, \mathbf{V} / \underline{b}, \mathbf{v}$ & - & ق & $\Xi$ & $\Xi$ \\
\hline $\mathrm{G} / \mathrm{g}$ & - & $\xi$ & $\rightarrow$ & $\rightarrow$ \\
\hline$\overline{\mathrm{G}} / \dot{\mathrm{g}}, \overline{\mathrm{G}}, \overline{\mathrm{g}}$ & $\dot{\varepsilon}$ & $\dot{\varepsilon}$ & $\rightarrow$ & $\rightarrow$ \\
\hline $\mathbf{C} / \mathbf{c}$ & $\tau$ & $\tau$ & - & $\Rightarrow$ \\
\hline $\mathrm{D} / \mathrm{d}$ & د & د & $\geq$ & 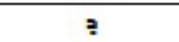 \\
\hline $\mathrm{D} / \mathrm{d}$ & $\dot{5}$ & j & $\vec{z}$ & $z$ \\
\hline $\mathrm{H} / \mathrm{h}$ & $=$ & $\Rightarrow$ & 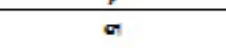 & a \\
\hline $\mathrm{W} / \mathrm{w}, \mathrm{U} / \mathrm{u}$ & g & و & 0 & 0 \\
\hline $\mathrm{Z} / \mathrm{z}$ & $j$ & $j$ & , & , \\
\hline $\mathrm{H} / \mathrm{h}$ & $\zeta$ & $\zeta$ & m & $m$ \\
\hline$T / t$ & b & b & $\rightarrow$ & $\rightarrow$ \\
\hline $\mathrm{Y} / \mathrm{y}$ & ي & ي & - & - \\
\hline $\mathrm{K} / \mathrm{k}$ & s & آك & 5 & 5 \\
\hline$\underline{\mathrm{K}}, \mathrm{H} / \mathrm{k}, \mathrm{h}$ & $\dot{\tau}$ & $\dot{\tau}$ & 5 & 5 \\
\hline $\mathrm{C}, \mathrm{CH} / \mathrm{c}, \mathrm{ch}$ & - & $\varepsilon$ & - & 5 \\
\hline $\mathrm{L} / 1$ & $J$ & J & $\Delta$ & $\Delta$ \\
\hline $\mathrm{M} / \mathrm{m}$ & 5 & 5 & 7 & $\boldsymbol{7}$ \\
\hline $\mathrm{N} / \mathrm{n}$ & $\dot{0}$ & ن & 2 & 2 \\
\hline \multirow[t]{2}{*}{$\mathrm{S} / \mathrm{s}$} & سن & نט & هـ & هـ \\
\hline & $\varepsilon$ & $\varepsilon$ & $\lambda$ & د \\
\hline $\mathrm{P}, \mathrm{F} / \mathrm{P}, \mathrm{f}$ & ف & $\dot{\omega}$ & $s$ & 3 \\
\hline $\mathrm{S} / \mathrm{s}$ & صن & صט & 5 & 5 \\
\hline $\mathrm{Q} / \mathrm{q}$ & ت & ث & $=$ & $=$ \\
\hline $\mathrm{R} / \mathrm{r}$ & $\jmath$ & $\jmath$ & 5 & $\mathbf{s}$ \\
\hline$\tilde{\mathrm{S}}_{z}, \mathrm{~S}_{\mathrm{S}} / \check{\mathrm{S}}_{z} \mathrm{~S}$ & ت & ت & $x$ & $x$ \\
\hline $\mathbf{J} / \mathbf{j}$ & - & 3 & - & 포 \\
\hline$T / t$ & 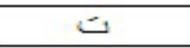 & 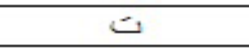 & A & $A$ \\
\hline$\underline{T} / \underline{t}$ & $\Xi$ & $\Xi$ & $\therefore$ & $\therefore$ \\
\hline
\end{tabular}

\begin{tabular}{|c|c|c|c|c|c|c|c|}
\hline & $\dot{\varphi}$ & 5 & 9 & $?$ & $\dot{a}$ & ? & 을 \\
\hline Fellĩhî & $\mathrm{A} / \mathrm{a}$ & $\overline{\mathrm{A}} / \overline{\mathrm{a}}$ & $\overline{\mathrm{E}} / \mathrm{e}, \mathrm{E} / \mathrm{e}$ & $\overline{\mathrm{U}} / \hat{\mathrm{u}}, \mathrm{U} / \mathrm{u}$ & $-\mathrm{O},-\mathrm{O}$ & $\overline{\mathrm{I} / \mathrm{i}}$ & $\mathrm{I} / \mathrm{i}$ \\
\hline Gerşûnî & $\mathrm{E} / \mathrm{e}$ & $\mathrm{A} / \mathrm{a}$ & $\bar{E} / \hat{\mathrm{e}}$ & $\overline{\mathrm{U}} / \hat{\mathrm{u}}, \mathrm{U} / \mathrm{u}$ & $-\mathrm{O},-\mathrm{O}$ & $\mathrm{I} / \mathrm{i}$ & $\mathrm{I} / \mathrm{i}$ \\
\hline
\end{tabular}




\section{EXTENDED ABSTRACT}

The phenomenon of travel has gained an important place in the recognition and definition of languages and cultures since history. Kurdistan has been a center of attraction for many travelers, especially after the 16th century. Due to the multicolored nature of Kurdistan, this tradition was also reinforced by missionary and diplomatism. Especially in the 19th century, Kurdistan hosted many missionaries, orientalists and travelers. As a result of these travels made for many different reasons, a great legacy has been left in the field of language, culture and literature. This manuscript that we are working on today is only one of hundreds of manuscripts in the field of Kurdish language and culture. Of course, these manuscripts do not belong only to a traveler, orientalist or a region of Kurdistan. These manuscripts have emerged as a result of the work of orientalists and travelers from many different ethnicities who have come into contact with the Kurds, Assyrians, Arabs and Armenians in many different regions of Kurdistan.

Eduard Sachau (1845-1930) is an orientalist who made two separate trips to Kurdistan in 1880 and 1898. During such visits, the orientalists were generally cordial with the madrasah and monastery circles, which constituted the literate and scholarly mass of that period. Because obtaining, translating, reading, and rewriting written sources could only be done by muddaris and monks. Sachau met an Assyrian monk named Jeremias Schamir (1821-1906) from Erbil Ainkawa on his first trip and received a lot of information and documents from him. These documents were especially in Syriac, Arabic and Kurdish fields. Religious or cultural texts related to these languages were collected, compiled and delivered to Eduard Sachau. Sometimes, Sachau privately asked Schamir to translate some texts into Syriac (Fellihi/Surat) and Kurdish for him. Generally, these texts were written with the Garshuni calligraphy, which was common among the Assyrians at that time. For this reason, it is possible to come across many Garshuni texts registered in the name of Eduard Sachau in the Collection of Orientalische Handschriften in the Berlin State Library-Prussian Cultural Heritage (Staatsbibliothek zu Berlin-Preußischer Kulturbesitz).

A manuscript in this collection is also recorded as Sachau 200 and a Kurdish Garshuni text in this manuscript constitutes the main subject of our article. There are nine chapters in total in the aforementioned manuscript. The tale of Arabian Nights we studied and which is at the end of the first chapter of manuscript was translated by Jeremias Schamir from Arabic to Kurdish and Syriac (Fellihi) with Garshuni calligraphy. As a result of our research, we saw that this tale was quoted from Faris el-Shidiac's book A Practical Grammar of the Arabic Language, which was prepared in English in 1856 to teach Arabic. In fact, we also figured out that Jeremias Schamir translated the entire book of el-Shidiac into Syriac (Fellihi) and Kurdish at the request of Eduard Sachau. However, we have only examined this tale, which was presented as a "reading practice" in this article.

In this study, first of all, the manuscript that we studied was introduced in general in terms of form and content. Then, the part of the tale that we worked on was introduced. However, after we transcribed the Kurdish and Syriac (Fellihi) forms of the mentioned tale, a comparison was made in terms of content, language and translation. Later, this tale, which was recorded as the tale of the One Hundred and Sixty-Second nights, was compared with today's Arabic, Persian, Kurdish (Sorani) and Turkish translations.

As a result, we brought to light a Kurdish translation of tale of Arabian Nights, written in Garshuni calligraphy in 1883. Besides, we found out that an Arabic-English grammar book was translated into Kurdish with Garshuni calligraphy in the same period. We also tried to show the mentality of translation in the 19th century. We observed that the understanding of translation at that time was method of word for word in the original book, Faris el-Shidiac's book A Practical Grammar of the Arabic Language, which was prepared in English in 1856 to teach Arabic. Likewise, we confirmed that the same method was followed in the Kurdish translation of Jeremiya Schamir. As Jeremy Munday, a translation scientist, stated, in the periods before the second half of the 20th century, the understanding of word for word translation was mostly based on textbooks. Since the translation we are working on is also a textbook exercise, he has once again justified Jeremy Munday. Perhaps most importantly, we have realized that many manuscripts written in Kurdish Garshuni calligraphy, similar to the work we studied, are waiting to be brought to light. 